\title{
Regulation of the arachidonic acid mobilization in macrophages by combustion-derived particles
}

Susanne Fritsch-Decker ${ }^{1}$, Tanja Both', Sonja Mülhopt ${ }^{2}$, Hanns-Rudolf Paur ${ }^{2}$, Carsten Weiss ${ }^{1}$ and Silvia Diabaté ${ }^{*}$

\begin{abstract}
Background: Acute exposure to elevated levels of environmental particulate matter (PM) is associated with increasing morbidity and mortality rates. These adverse health effects, e.g. culminating in respiratory and cardiovascular diseases, have been demonstrated by a multitude of epidemiological studies. However, the underlying mechanisms relevant for toxicity are not completely understood. Especially the role of particle-induced reactive oxygen species (ROS), oxidative stress and inflammatory responses is of particular interest.

In this in vitro study we examined the influence of particle-generated ROS on signalling pathways leading to activation of the arachidonic acid (AA) cascade. Incinerator fly ash particles (MAF02) were used as a model for reallife combustion-derived particulate matter. As macrophages, besides epithelial cells, are the major targets of particle actions in the lung murine RAW264.7 macrophages and primary human macrophages were investigated.

Results: The interaction of fly ash particles with macrophages induced both the generation of ROS and as part of the cellular inflammatory responses a dose- and time-dependent increase of free AA, prostaglandin $E_{2} /$ thromboxane $\mathrm{B}_{2}\left(\mathrm{PGE}_{2} / \mathrm{TX} \mathrm{B}_{2}\right)$, and 8-isoprostane, a non-enzymatically formed oxidation product of $\mathrm{AA}$. Additionally, increased phosphorylation of the mitogen-activated protein kinases (MAPK) JNK1/2, p38 and ERK1/2 was observed, the latter of which was shown to be involved in MAF02-generated AA mobilization and phosphorylation of the cytosolic phospolipase $A_{2}$. Using specific inhibitors for the different phospolipase $A_{2}$ isoforms the MAF02-induced AA liberation was shown to be dependent on the cytosolic phospholipase $A_{2}$, but not on the secretory and calcium-independent phospholipase $A_{2}$. The initiation of the AA pathway due to MAF02 particle exposure was demonstrated to depend on the formation of ROS since the presence of the antioxidant $\mathrm{N}$-acetyl-cysteine (NAC) prevented the MAF02-mediated enhancement of free AA, the subsequent conversion to $\mathrm{PGE} / \mathrm{TX} \mathrm{B}_{2}$ via the induction of COX-2 and the ERK1/2 and JNK1/2 phosphorylation. Finally we showed that the particle-induced formation of ROS, liberation of $A A$ and $\mathrm{PGE}_{2} / T \mathrm{~TB}_{2}$ together with the phosphorylation of ERK $1 / 2$ and JNK1/2 proteins was decreased after pre-treatment of macrophages with the metal chelator deferoxamine mesylate (DFO).

Conclusions: These results indicate that one of the primary mechanism initiating inflammatory processes by incinerator fly ash particles seems to be the metal-mediated generation of ROS, which triggers via the MAPK cascade the activation of AA signalling pathway.
\end{abstract}

\section{Background}

Over the last decades a multitude of epidemiological studies could correlate elevated levels of environmental particulate matter (PM) with increasing cardiorespiratory morbidity and mortality rates [1,2], predominantly in susceptible individuals or humans with pre-existing

\footnotetext{
* Correspondence: silvia.diabate@kit.edu

${ }^{1}$ Karlsruhe Institute of Technology, Campus North, Institute of Toxicology and Genetics, Hermann-von-Helmholtz-Platz 1, 76344 EggensteinLeopoldshafen, Germany

Full list of author information is available at the end of the article
}

pulmonary or cardiovascular diseases [3-6]. Inflammation is considered as a major factor contributing to adverse health effects in response to elevated concentrations of ambient PM and nanoparticles [7-10]. Furthermore, the respiratory and systemic inflammatory effects have been associated with the induction of oxidative stress $[11,12]$.

Alveolar macrophages, besides epithelial cells, are the major targets of particle actions in the lung and play a key role in particle-induced inflammation and lung diseases. Thus, it has been shown in vitro that bronchial
C Biomed Central 
epithelial cells as well as alveolar macrophages release interleukin (IL)-8, and tumor necrosis factor- $\alpha$ (TNF- $\alpha$ ) in response to respirable particles [13-16]. In addition, treatment of monocytes and macrophages with PM results in an increased liberation of arachidonic acid and enhances formation of inflammatory mediators [17-19].

Arachidonic acid (AA) released from membrane phospholipids by phospholipases $\mathrm{A}_{2}\left(\mathrm{PLA}_{2}\right)$ serves as the precursor for a family of lipid mediators formed by oxygenation through the cyclooxygenase (COX) and lipoxygenase (LOX) pathways. The generation of lipid mediators, also called eicosanoids, plays a central role in cellular homeostasis, host defense and inflammatory processes. Therefore, a deregulation of AA metabolism can lead to the development of many oxidative stress related diseases such as pulmonary fibrosis and lung cancer [20-23]. Oxidants such as $\mathrm{H}_{2} \mathrm{O}_{2}$ have been reported to trigger AA release and its metabolism, involving multiple enzymes and pathways [24-26]. In this context, various studies revealed, that particles trigger the generation of reactive oxygen species and oxidative stress, resulting in an increased production of inflammatory mediators $[27,28]$. Brown and colleagues [29] demonstrated in primary alveolar macrophages and human monocytes that exposure to ultrafine carbon black particles triggers nuclear translocation of the transcription factor NF- $\kappa \mathrm{B}$ as well as an increased TNF- $\alpha$ protein release, two responses which were reduced by the antioxidant nacystelin (NAL). In addition, the antioxidant $\mathrm{N}$-acetyl-cysteine (NAC) also suppressed the cyclooxygenase-2 (COX-2) induction, prostaglandin $\mathrm{E}_{2}$ $\left(\mathrm{PGE}_{2}\right)$ synthesis and activation of the transcription factor NF- $\kappa \mathrm{B}$ by organic components of combustion derived particles, emphasizing the important role of ROS in particle-mediated inflammation [30]. Several studies supported an influence of transition metals, which are abundant constituents of ambient particulate matter, in mediating particle-induced formation of ROS [31]. Voelkel et al. [32] demonstrated a protective effect of the metal chelator DFO on fly-ash-induced formation of ROS. Furthermore, human studies have shown that the instillation of extracts of PM with a high metal content induced a stronger influx of inflammatory cells compared with particles with smaller metal content [33].

Recently, Beck-Speier et al. [34] reported that extracellularly insoluble $\mathrm{Fe}_{2} \mathrm{O}_{3}$ particles are partly soluble intracellularly which modulates the particle-mediated IL- 6 and PGE $_{2}$ release in vitro and in vivo. This demonstrates that even small amounts of bioavailable metals are able to activate inflammatory processes including the arachidonic acid cascade.

In a previous study we used the fly ash MAF02 originating from a municipal waste incinerator facility as a model for real-life combustion-derived particulate matter (PM) to study the in vitro responses in RAW264.7 macrophages [17]. We have shown that MAF02 particles induced an increased mobilization of AA and enhanced expression of COX-2 protein. Furthermore, the fly ash-induced AA mobilization was shown to be dependent on activation of the mitogenactivated protein kinases (MAPKs) ERK1/2 and to a lesser extent on p38. These processes were accompanied by the intracellular formation of ROS which resulted in the upregulation of various oxidative stress markers such as the increase of the cellular glutathione (GSH) content and the induction of the antioxidative enzyme heme oxygenase-1 (HO-1). The main focus of the present study was to elucidate the role of ROS in the activation of AA cascade in macrophages, and to examine which constituents of MAF02 particles are responsible for the cellular effects.

Our results revealed that exposure to MAF02 particles induces an activation of the arachidonic acid cascade in the murine macrophage cell line RAW264.7 as well as in human primary monocyte-derived macrophages (MDM) which was correlated with particle uptake into the cells. Particle-induced mobilization of AA requires the activation of ERK $1 / 2$ and is mediated through the activation of the cytosolic phospholipase $\mathrm{A}_{2}\left(\mathrm{CPLA}_{2}\right)$. Furthermore, initiation of the AA cascade is dependent on the formation of ROS. Analysis of the signalling pathways demonstrated that pre-treatment of macrophages with the antioxidant NAC leads to a significantly reduced mobilization of AA accompanied by a decreased activation of the ERK1/2 and JNK1/2 pathways as well as reduced induction of COX-2 and release of inflammatory lipid mediators. In addition, the metal chelator DFO prevented the MAF02-induced generation of ROS, the activation of downstream MAPK signalling and the arachidonic acid cascade. In summary, these data provide evidence for the involvement of metal-derived ROS formation in mediating particle-induced initiation of the inflammatory arachidonic acid cascade.

\section{Results}

\section{Particle characterization}

The MAF02 fly ash particles used in this study as a model for combustion-derived PM are composed of a large number of components. The water-soluble fraction of MAF02 was determined to $61 \%$ by weight when extracted with deionised water. Elemental analysis revealed that the major components of MAF02 were $\mathrm{Na}$, $\mathrm{K}$, and $\mathrm{Ca}$ which mainly occur as water-soluble salts (chlorides and sulphates). The major trace metals in MAF02 fly ash were $\mathrm{Zn}, \mathrm{Pb}$ and Fe which amount to $15.2,5.1$ and $1.7 \%$ of weight, respectively. $63 \%$ of $\mathrm{Zn}$, $81 \%$ of $\mathrm{Pb}$ and $87 \%$ of $\mathrm{Fe}$ were not extractable with 
water. Elemental carbon amounted to $7 \mathrm{mg} / \mathrm{g}$. Previous analysis of the particle size distribution by scanning mobility particle sizing (SMPS) after resuspension in air showed that the number concentration was dominated by fine and ultrafine particles with a modal value of 165 nm [13]. Additional analyses using a light scattering spectrometer detecting the particle sizes up to $10 \mu \mathrm{m}$ (PCS-2000) and scanning electronic microscopy (SEM) of deposited particles confirmed the low percentage of large agglomerates (Figure 1A-B).

\section{Uptake of fly ash particles}

In order to examine the uptake and cellular distribution of MAF02 particles in macrophages, transmission electron microscopy (TEM) images of murine RAW264.7 cells, incubated with $50 \mu \mathrm{g} / \mathrm{ml}\left(10.4 \mu \mathrm{g} / \mathrm{cm}^{2}\right)$ fly ash particles, were analyzed. TEM analysis demonstrated that MAF02 fly ash particles were taken up by RAW264.7 macrophages in dependence of time within the exposure period of $1 \mathrm{~h}$ up to $5 \mathrm{~h}$ (Figure $1 \mathrm{C}-\mathrm{F}$ ). The images present single and agglomerated particles in the intracellular space. Some are surrounded by a membrane, others not. No particles were observed within mitochondria or nuclei.

\section{Viability and ROS production in fly-ash treated RAW264.7} cells in comparison to human MDM

The dose-response curves of the effects of MAF02 particles on the viability and the intracellular ROS formation of RAW264.7 macrophages are published in Fritsch et al. [17]. To determine whether the transformed murine macrophage cell line represents an appropriate in vitro model system, we compared the dose-response curves to those obtained with human monocyte-derived macrophages (MDM). As shown in Figure 2 the murine cell line RAW264.7 responds similar to MDM when exposed to MAF02 particles and therefore seems to be a proper model system. For the experiments presented in the following we used a maximal MAF02 concentration of 50 $\mu \mathrm{g} / \mathrm{ml}\left(15.6 \mu \mathrm{g} / \mathrm{cm}^{2}\right)$ which did not affect viability after $24 \mathrm{~h}$ but induced a moderate increase of intracellular ROS levels after $3 \mathrm{~h}$.
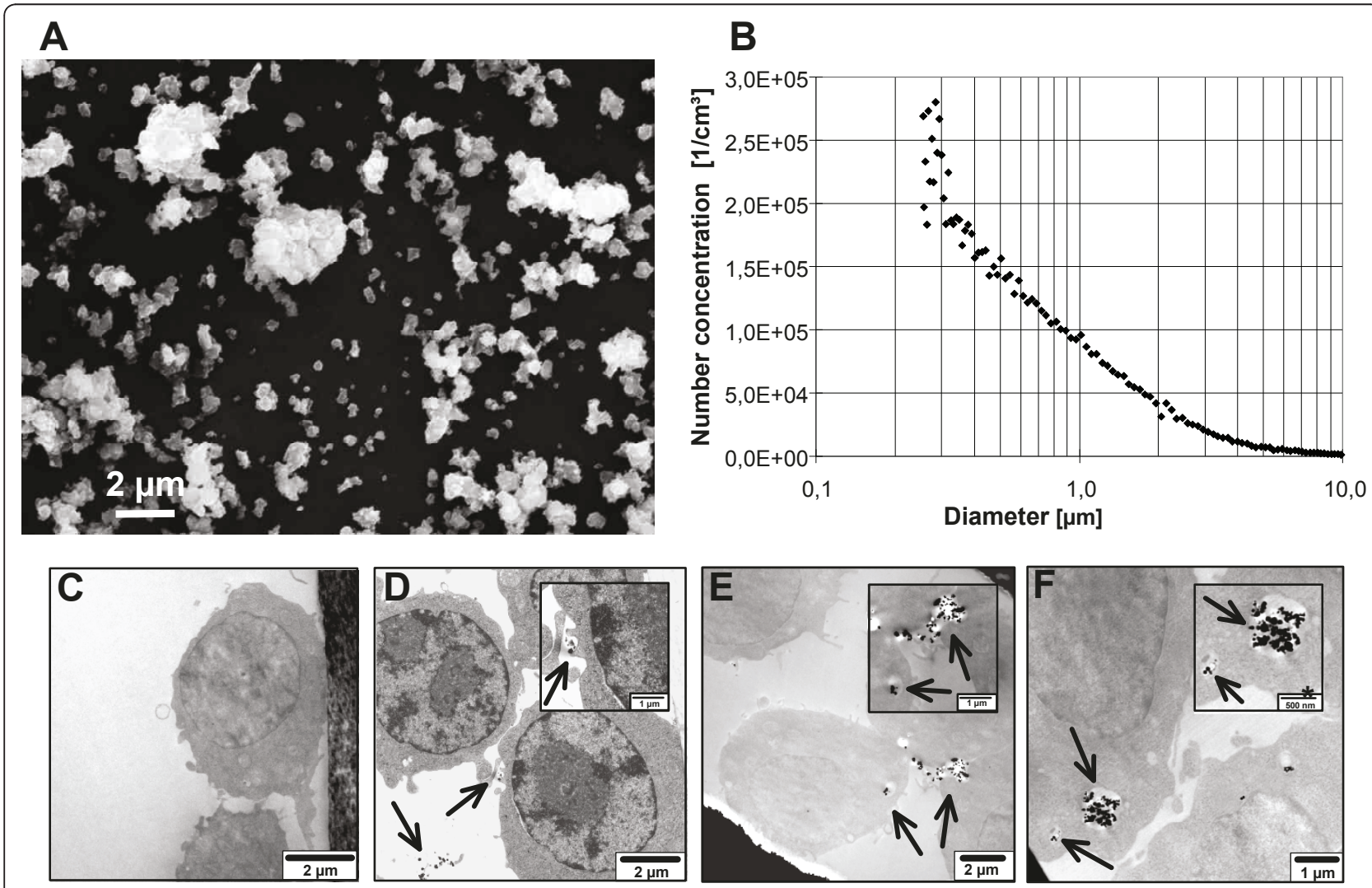

Figure 1 Characterization and uptake of MAF02 particles. The fly ash was resuspended in filtered air, deposited on a Nuclepore membrane and analyzed by SEM (A). The bar indicates $2 \mu \mathrm{m}$. The aerosol was additionally measured by PCS-2000 light scattering spectrometer (B). The graph is representative of three measurements. For TEM analysis RAW264.7 cells were left untreated (C) or exposed to $50 \mu \mathrm{g} / \mathrm{ml}$ MAF02 particles $\left(10.4 \mu \mathrm{g} / \mathrm{cm}^{2}\right)$ for $1 \mathrm{~h}(\mathrm{D}), 2.5 \mathrm{~h}$ (E) or $5 \mathrm{~h}$ (F). Representative images of three different experiments are shown. Arrows indicate MAF02 particles in agglomerates of different sizes. 
A

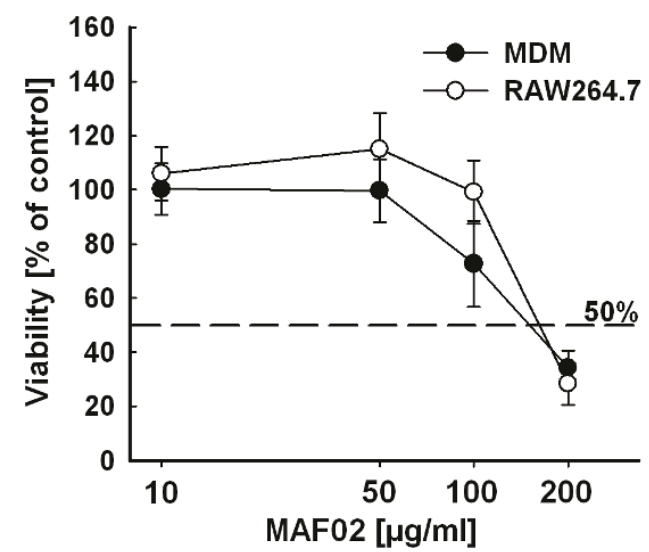

B

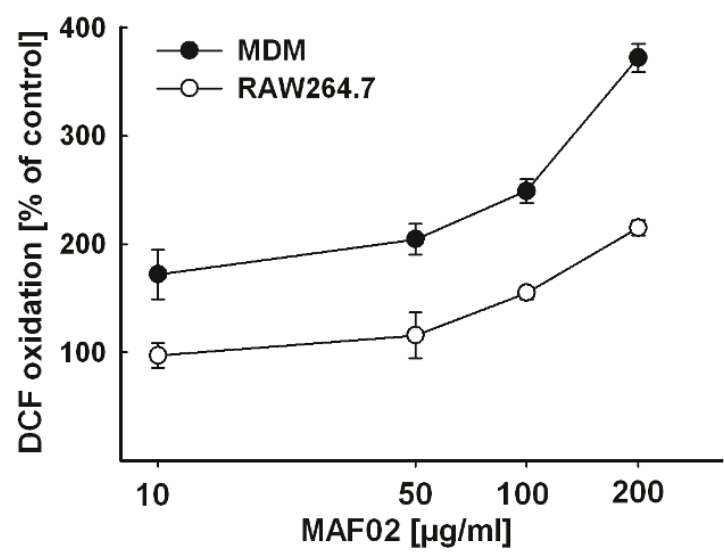

Figure 2 MAF02 reduces the viability of human MDM and RAW264.7 macrophages and induces intracellular ROS in dependence of dose. (A) For testing viability human MDM and RAW264.7 macrophages were treated with MAF02 particles at 10, 50, $100 \mathrm{and} 200 \mathrm{\mu g} / \mathrm{ml}(6.3$, $31.3,62.5$ and $125 \mathrm{\mu g} / \mathrm{m}^{2}$ ) for 20 hours. The viability was analyzed using the WST-1 assay and results are given in percentage of untreated controls. (B) For studying ROS formation macrophages were treated with the same particle concentrations for $3 \mathrm{~h}$ and subsequently loaded with $\mathrm{H}_{2} \mathrm{DCF}$. Induction of ROS was detected by fluorescence measurement of DCF and changes in fluorescence intensity are expressed as percentage of untreated controls. Results are the mean \pm s.e.m. of three independent experiments, each carried out in triplicate.

Fly ash exposure induces liberation of arachidonic acid in RAW264.7 cells and human MDM

AA mobilization in RAW264.7 macrophages was dependent on dose and time as already shown previously [17]. To provide further evidence that RAW264.7 cells serve as a reliable and accurate model system to investigate particle-induced cellular inflammatory processes, we compared the influence of MAF02 on AA mobilization to primary human MDMs. As shown in Figure 3B, we observed a moderate increase of AA mobilization in MDM. However, while a dose of $50 \mu \mathrm{g} / \mathrm{ml}(13.2 \mu \mathrm{g} /$ $\mathrm{cm}^{2}$ ) MAF02 particles induced a 6-fold increase above the basal level of free AA in RAW264.7 cells after 5 h, a 1.8-fold increase was observed in MDM under the same exposure conditions. The lower potential of MAF02mediated AA mobilization in MDM in comparison to RAW264.7 macrophages might be explained by a decreased expression of the key enzyme of AA mobilization, the $\mathrm{CPLA}_{2}$, in the primary cells compared to the mouse cell line (data not shown).

Fly ash exposure induces the release of the AAderivatives $\mathrm{PGE}_{2} / \mathrm{TXB}_{2}$ and 8-isoprostane

Free AA can be metabolized into prostaglandins and thromboxanes by oxygenation via the cyclooxygenase (COX) pathway. Two isoforms of the COX have been identified, COX-1, which is constitutively expressed, and COX-2, which can be induced by various inflammatory and proliferative stimuli $[35,36]$. Additionally, AA incorporated into phospholipids can be non-enzymatically converted to isoprostanes by free radical-initiated peroxidation.

The effect of MAF02 particles on activation of the AA pathway prompted us to investigate whether the increased liberation of AA is accompanied by elevated levels of AA-metabolites. Previously we could show an induction of COX-2 by MAF02 particles, whereas no increase in COX-1 protein was observed (data not shown). As shown in Figure 3C, a low dose of MAF02 at $50 \mu \mathrm{g} / \mathrm{ml}\left(10.4 \mu \mathrm{g} / \mathrm{cm}^{2}\right)$ induced a release of $\mathrm{PGE}_{2} /$ $\mathrm{TXB}_{2}$ from RAW264.7 cells in a time-dependent manner up to 5 hours of exposure. Similarly, exposure to the same concentrations and time periods led to the release of 8 -isoprostane (Figure 3D), one of the most abundant isoprostanes, which serves as reliable biomarker of oxidative stress.

Fly ash-induced liberation of arachidonic acid is regulated by cytosolic phospholipase $A_{2}$

The AA, normally incorporated at the sn- 2 position of phospholipids, can be released by activated phospholipases $\mathrm{A}_{2}\left(\mathrm{PLA}_{2}\right)$. The protein superfamily of phospholipases $\mathrm{A}_{2}$ includes the secretory $\left(\mathrm{sLA}_{2}\right)$, the cytosolic $\left(\mathrm{cPLA} A_{2}\right)$, and the $\mathrm{Ca}^{2+}$-independent $\mathrm{PLA}_{2}\left(\mathrm{iPLA}_{2}\right)$. Hence the next question was which of the $\mathrm{PLA}_{2}$ are involved in the MAF02-induced AA mobilization. To analyze the influence of these $\mathrm{PLA}_{2}$ on MAF02-induced AA liberation different $\mathrm{PLA}_{2}$ inhibitors were used. The RAW264.7 macrophages were preincubated with certain concentrations of specific inhibitors for the respective 


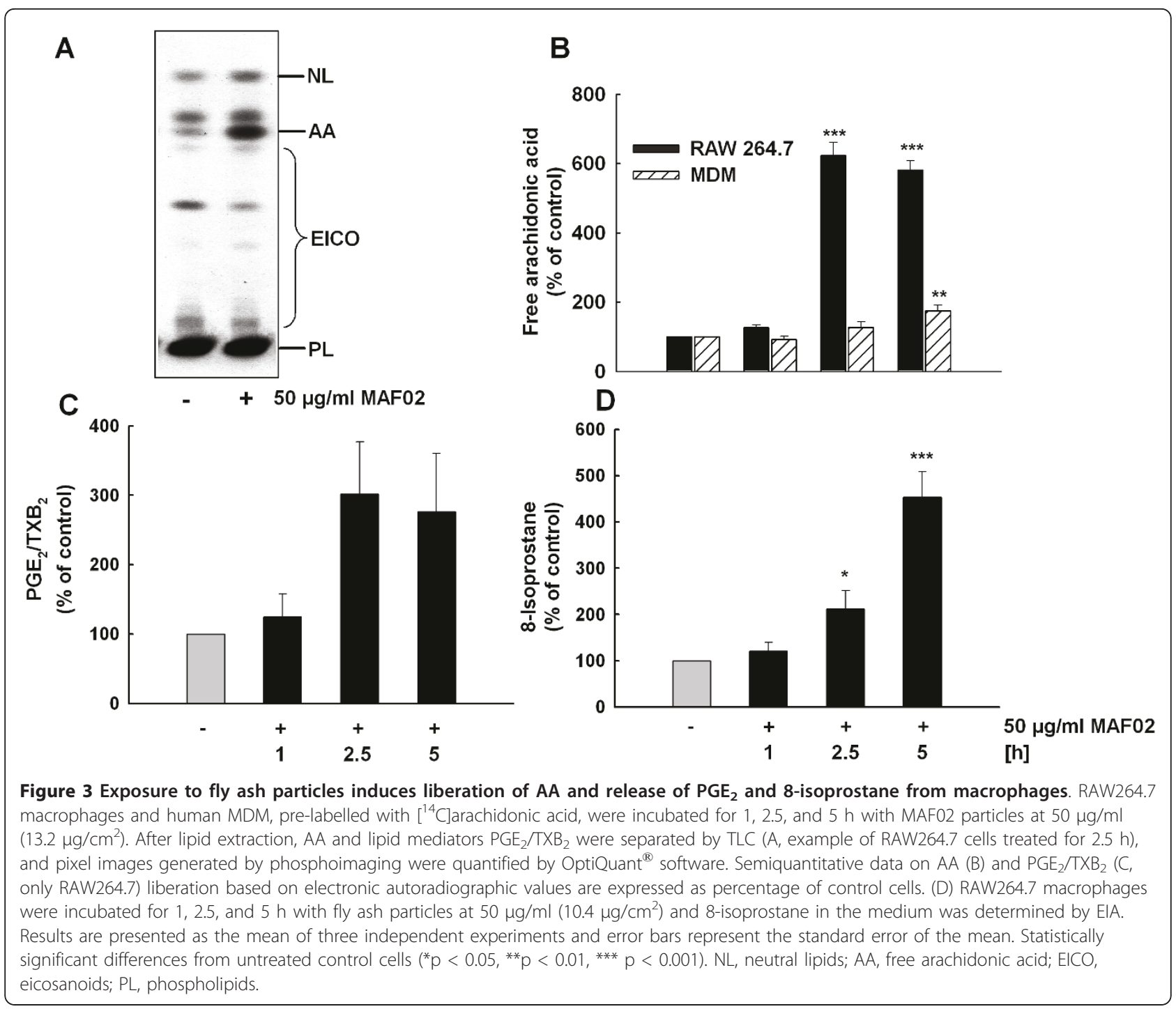

$\mathrm{PLA}_{2}$ isoform for 30 minutes and then treated with 50 $\mu \mathrm{g} / \mathrm{ml}\left(13.2 \mu \mathrm{g} / \mathrm{cm}^{2}\right)$ MAF02 particles over a period of 2.5 hours (Figure $4 \mathrm{~A}$ ).

Thioetheramide-phosphatidylcholine (TEA-PC), a specific inhibitor of the $\mathrm{SPLA}_{2}$ is an analogue of phosphatidylcholine, containing a thioether at the sn-1 position and an amide at the sn- 2 position. Thereby it functions as a competitive, reversible inhibitor of $\mathrm{sPLA}_{2}$ [37]. In the experiment the preincubation with $10 \mu \mathrm{M}$ TEA-PC reduced the particle-induced AA mobilization to approximately $60 \%$, which however was not significant.

Treatment with $50 \mu \mathrm{M}$ arachidonyltrifluoromethylketone $\left(\mathrm{AACOCF}_{3}\right)$ most effectively inhibited the MAF02-induced liberation of arachidonic acid down to $25 \% . \mathrm{AACOCF}_{3}$ is a plasma membrane substrate analogue of arachidonic acid [38], which blocks the catalytic center of the cPLA 2 by binding to serine reversibly. At higher concentrations it can also inhibit the iPLA 2 while sPLA $_{2}$ is not affected [39].

In order to investigate whether the $\mathrm{iPLA}_{2}$ also plays a role in the mobilization of AA in RAW264.7 macrophages, bromoenol lactone (BEL) as a selective, irreversible inhibitor of this enzyme was used [39]. As shown in Figure $4 \mathrm{~A}$ the preincubation of the cells with $5 \mu \mathrm{M}$ BEL had no significant influence on the particle-induced liberation of AA in comparison to macrophages, which were only treated with fly ash particles. Therefore it could be excluded that the $\mathrm{PLLA}_{2}$ was involved in the MAF02-triggered mobilization of AA. This also demonstrates that the reduction of the MAF02-induced AA mobilization by $\mathrm{AACOCF}_{3}$ was only due to inhibition of the $\mathrm{CPLA}_{2}$ but not of the iPLA .

In summary, the cytosolic PLA 2 and to a minor extent the secretory $\mathrm{PLA}_{2}$ but not the calcium-independent 


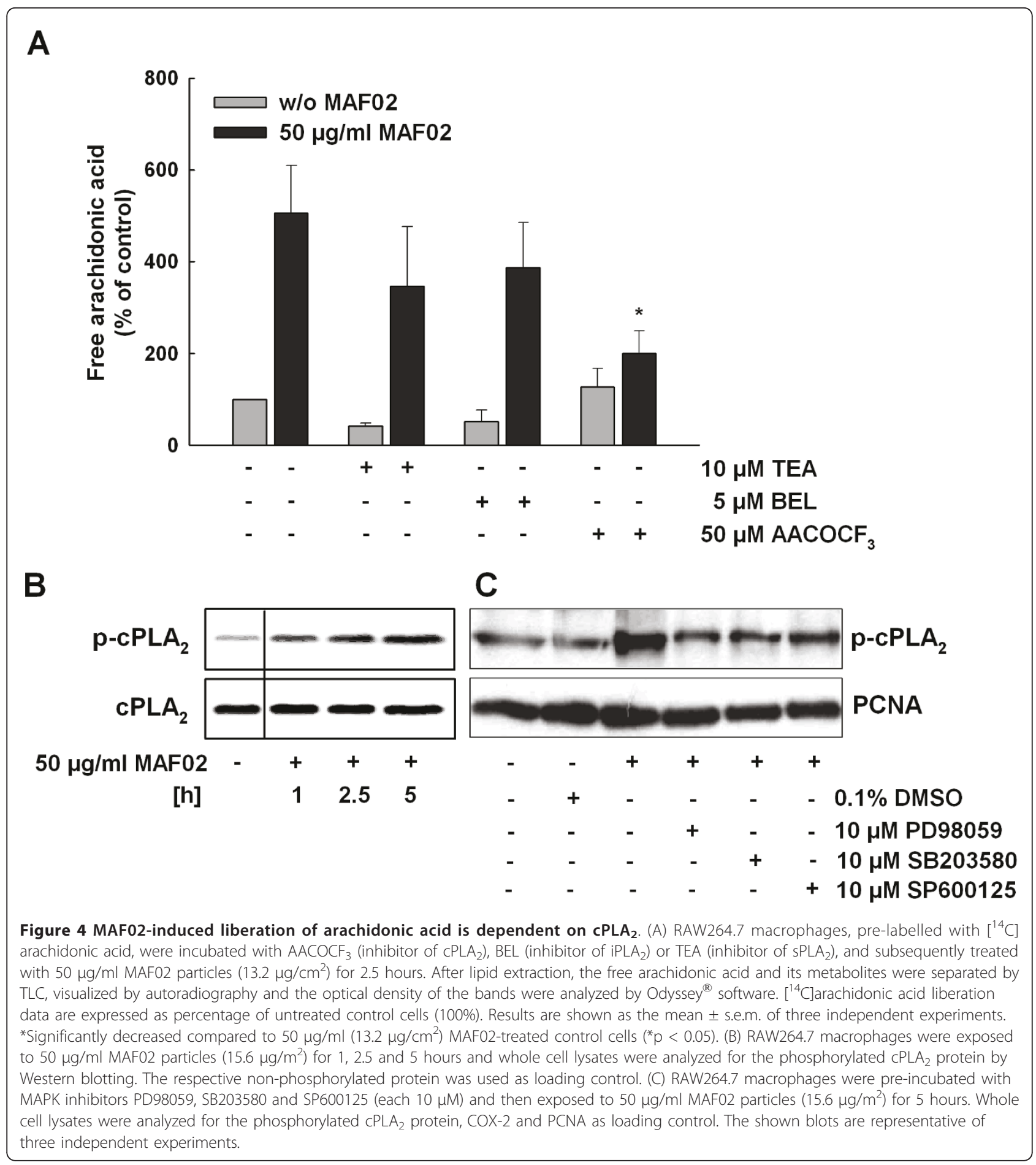

$\mathrm{PLA}_{2}$ are involved in the process of MAF02-induced liberation of arachidonic acid.

The CPLA $_{2}$ activation is mediated by its phosphorylation [40]. Therefore, we analyzed the phosphorylation status of $\mathrm{CPLA}_{2}$ in response to MAF02 fly ash. Indeed, we detected an increase of the phosphorylated form of $\mathrm{cPLA}_{2}$ in RAW264.7 macrophages after treatment with MAF02 particles at $50 \mu \mathrm{g} / \mathrm{ml}(15.6 \mu \mathrm{g} /$ $\mathrm{cm}^{2}$ ) by Western blot analysis using phospho-specific antibodies. In correlation with the inhibitor studies the degree of $\mathrm{CPLA}_{2}$ phosphorylation increased in a timedependent manner from one hour to five hours of exposure and thus paralleled the enhanced AA liberation (Figure 4B). 
We furthermore investigated by specific inhibitors if the MAPKs ERK1/2, JNK1/2 and p38 contribute to the MAF02-induced $\mathrm{cPLA}_{2}$ phosphorylation. As shown in Figure $4 \mathrm{C}, \mathrm{CPLA}_{2}$ phosphorylation was reduced by PD98059, an inhibitor of the upstream kinase MEK1/2 which is responsible for ERK1/2 activation and by SB203580, an inhibitor of p38 activation. However, SP600125, an inhibitor of JNK1/2 activation, less efficiently blocked cPLA 2 phosphorylation. A similar profile was observed for the induction of MAF02-induced expression of COX-2, which was prevented by the MEK $1 / 2$ and the p38 inhibitor but not by the JNK $1 / 2$ inhibitor.

\section{MAP kinases contribute to MAF02-induced AA mobilization}

Using phospho-specific antibodies we detected increased phosphorylation of ERK1/2 and JNK1/2 after treatment with fly ash in dependence of time, reaching its maximum after 5 hours. On the other hand, p38 MAPK was only weakly phosphorylated after treatment of RAW264.7 cells with MAF02 particles (Figure 5B). Only inhibition of the ERK1/2 pathway with PD98059 lead to a significant reduction of AA mobilization (Figure 5A) confirming the contribution of ERK $1 / 2$ in activation of the cPLA $_{2}$ already shown in Figure $4 \mathrm{C}$. The p38 and JNK1/2 inhibitors only moderately reduced the fly ashmediated liberation of AA but not significantly.

Again, the primary human MDM showed a similar time-dependent increase of ERK $1 / 2$ and JNK1/2 phosphorylation as well as an even stronger activation of p38 MAPK (Figure 5C).

\section{NAC reduces fly ash-induced signalling and AA mobilization}

To explore the involvement of ROS in MAF02-mediated AA mobilization, RAW264.7 macrophages were preincubated for $30 \mathrm{~min}$ with the antioxidant NAC prior to fly ash exposure. We observed in RAW264.7 macrophages that fly ash-induced production of ROS (Figure 6A), phosphorylation of ERK1/2 (Figure 6B), mobilization of AA (Figure 6C) as well as COX-2 protein expression (Figure 6D) together with the release of $\mathrm{PGE}_{2} / \mathrm{TXB}_{2}$ (Figure $6 \mathrm{E}$ ) were inhibited by $5 \mathrm{mM} \mathrm{NAC}$ nearly completely, while $1 \mathrm{mM}$ NAC had only a weak effect on the induction of these processes. In contrary, fly ash-induced phosphorylation of c-Jun (Figure 6F) together with activation of JNK1/2 (data not shown) were inhibited almost completely with only $1 \mathrm{mM}$ NAC while AA liberation is still induced and only totally blocked at $5 \mathrm{mM}$. Together with the fact that inhibition of JNK did not reduce AA mobilization as shown above we conclude that JNK signalling seems not to be involved in mobilization of AA and its metabolites. The observed fly ash-induced activation of JNK $1 / 2$ and c-Jun may trigger other endpoints, which were not further studied. Thus, MAF02 fly ash exerts its effects via the formation of ROS, which is a prerequisite for the activation of the MAPK pathways and mobilization of AA via activation of $\mathrm{CPLA}_{2}$, and its subsequent conversion by COX-2 to the lipid mediators $\mathrm{PGE}_{2} / \mathrm{TXB}_{2}$.

\section{The water-insoluble fraction of MAF02 is responsible for AA mobilization}

To examine whether the water-soluble or insoluble fraction of MAF02 are involved in the fly ash-induced activation of the AA cascade, RAW264.7 macrophages were exposed for $2.5 \mathrm{~h}$ to $50 \mu \mathrm{g} / \mathrm{ml}\left(13.2\right.$ to $\left.15.6 \mu \mathrm{g} / \mathrm{cm}^{2}\right)$ of the total, water-insoluble (pellet) or water-soluble (supernatant) fraction of fly ash particles (Figure 7). We observed that exposure of macrophages to the waterinsoluble pellet fraction of MAF02 particles induced a marked $\mathrm{AA}$ and $\mathrm{PGE}_{2} / \mathrm{TXB}_{2}$ mobilization similar to the liberation of AA and its metabolites in cells treated with the total fraction of fly ash particles. In contrast, the soluble fraction of MAF02 did not induce any significant increase in $\mathrm{AA}$ and $\mathrm{PGE}_{2} / \mathrm{TXB}_{2}$ release, indicating that the water-insoluble fraction of MAF02 causes the cellular particle-induced effects. In addition, while exposure of RAW264.7 cells to the pellet fraction of fly ash resulted in an enhanced phosphorylation of ERK1/2 and of the transcription factor c-Jun, the supernatant fraction did not activate ERK1/2 and c-Jun. These results indicate that the metals which are still incorporated in the glass-like matrix of the water-insoluble fraction and probably become soluble intracellularly due to the low $\mathrm{pH}$ within lysosomes are responsible for the detected cellular events.

\section{DFO reduces fly ash-induced signalling and AA mobilization}

Several studies have demonstrated that redox-active metals in particular iron and zinc of ambient particulate matter can induce an increased production of ROS which may lead to oxidative stress. The water-insoluble pellet fraction of MAF02 particles consists of appreciable amounts of zinc and iron which could cause the generation of ROS by e.g. an iron-mediated Fenton-like reaction. In order to investigate an association between the metal content of MAF02 particles and activation of the AA cascade the metal chelator DFO was added to the RAW264.7 macrophages prior to stimulation with fly ash particles for $2.5 \mathrm{~h}$. Pre-treatment of macrophages with DFO resulted in a decreased particle-induced formation of ROS (Figure 8A) and prevented the subsequent phosphorylation of the ERK1/2 MAPK 


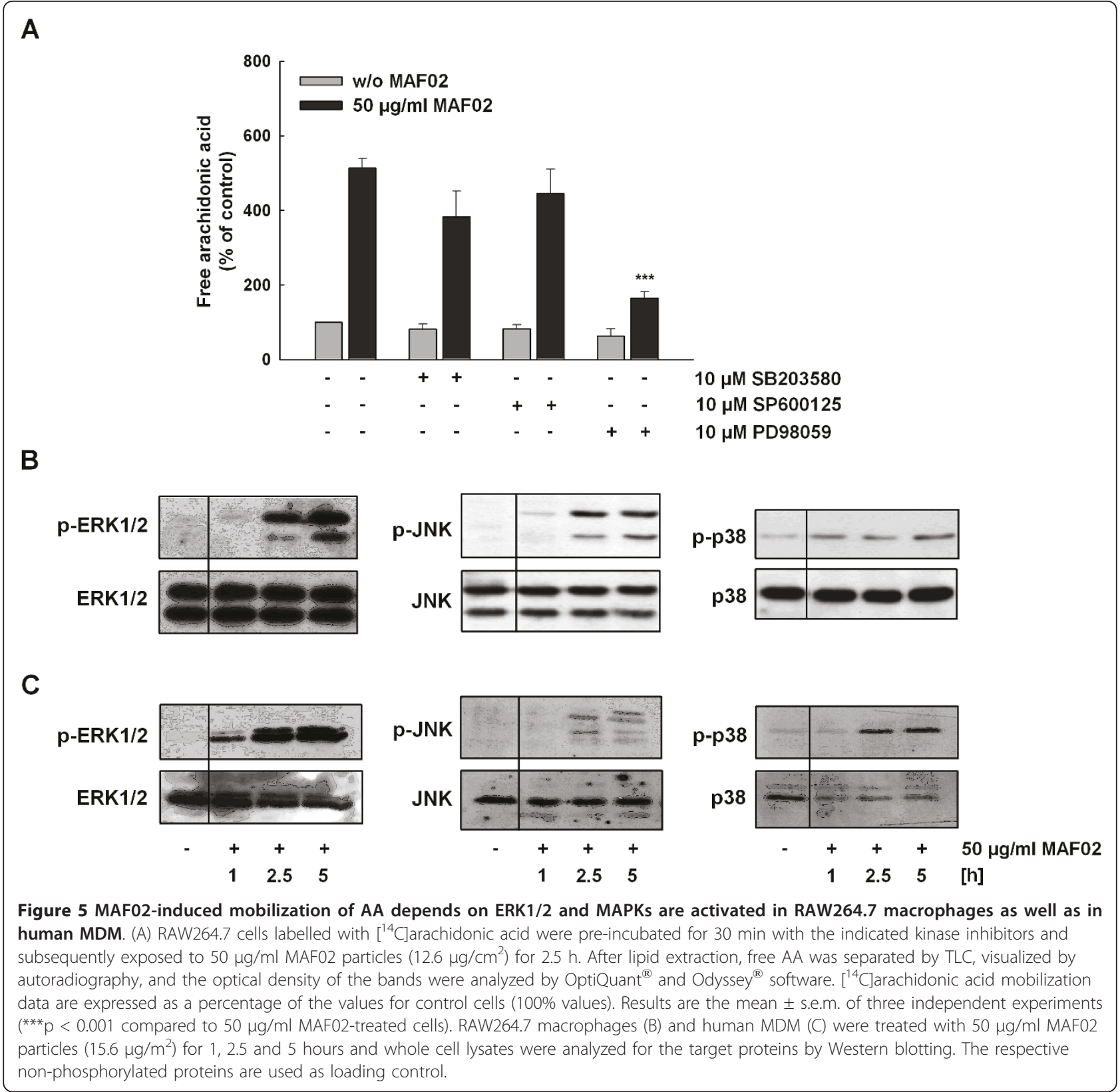

(Figure $8 \mathrm{~B}$ ), together with the liberation of AA (Figure $8 \mathrm{C}$ ) and its metabolization to $\mathrm{PGE}_{2} / \mathrm{TXB}_{2}$ (Figure $8 \mathrm{D}$ ). Phosphorylation of JNK and c-Jun was also inhibited by DFO (Figure 8E-F). The clear inhibition of these effects by DFO as well as the observation that only the waterinsoluble fraction is responsible for the effect (Figure 7) demonstrates that the MAF02 particles induce activation of the AA signalling pathway by metals which are included in the water-insoluble matrix, but which may become bioavailable inside the cell. The effects of DFO on the AA pathway support the hypothesis that activation of the AA cascade by fly ash particles depends on metal-mediated ROS formation.

\section{Discussion}

Many studies detected multiple effects of PM on e.g. inflammatory pathways in different cell types but the challenge is to identify the key mechanisms which initiate all these pleiotropic downstream responses. Here we pinpoint the critical role of metals in PM initiated inflammatory signalling in macrophages. In the following we discuss the underlying mechanisms of signal transduction and how this relates to findings observed with other types of PM.

Our studies focused on the MAF02-induced inflammatory processes with special emphasis on the regulation of the AA metabolism. AA liberation and its metabolization 
A

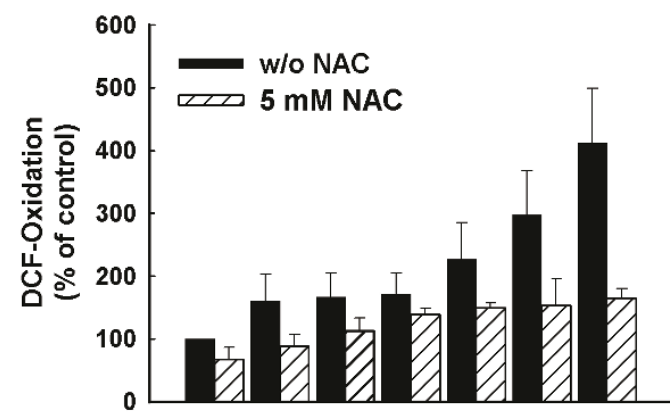

$\begin{array}{lllllll}0 & 10 & 25 & 50 & 100 & 200 & 300\end{array}$

\section{C}

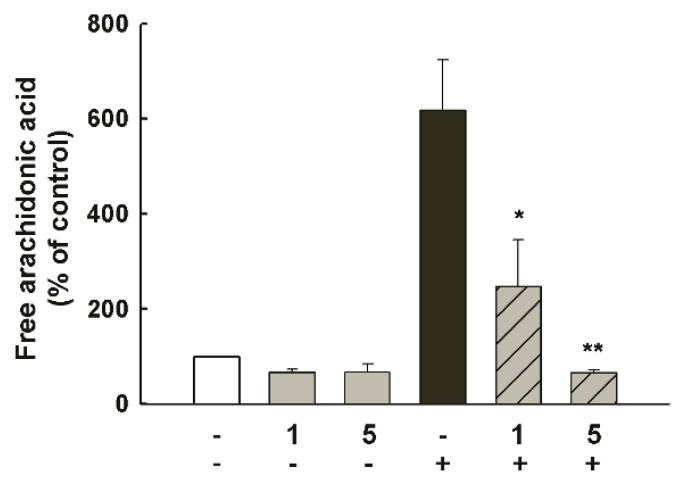

B

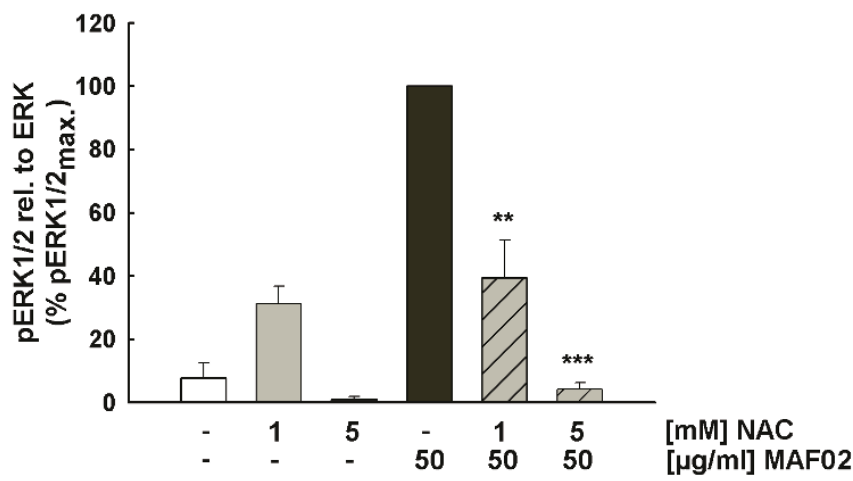

D

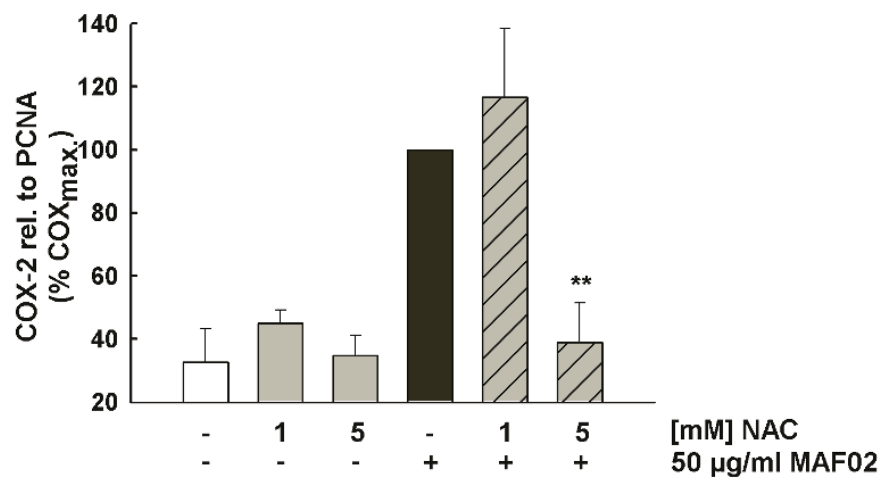

$\mathbf{F}$

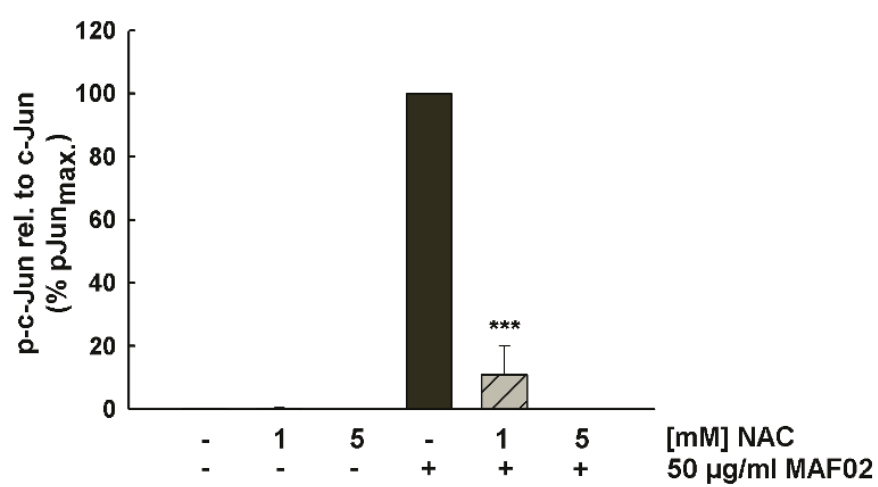

Figure 6 NAC inhibits fly ash-induced formation of ROS, mobilization of AA, phosphorylation of ERK1/2, JNK, C-Jun and COX-2 expression. (A) Adherent $\mathrm{H}_{2}$ DCF-loaded RAW264.7 cells were pre-incubated with $5 \mathrm{mM} \mathrm{NAC}$ and further incubated with 10, 25, 50, 100, 200 and $300 \mu \mathrm{g} / \mathrm{ml}$ fly ash particles $\left(6.3,12.6,31.3,62.5,125,188 \mu \mathrm{g} / \mathrm{cm}^{2}\right)$ for 2.5 hours. Values are expressed as a percentage of the untreated controls. For analysis of ERK1/2 (B), C-Jun (F) phosphorylation, and COX-2 expression (D), non-labelled cells were pre-incubated with NAC at 1 and/or $5 \mathrm{mM}$ and further treated with $50 \mu \mathrm{g} / \mathrm{ml}$ MAF02 particles $\left(15.6 \mu \mathrm{g} / \mathrm{m}^{2}\right)$ for 2.5 hours. Whole cell lysates were analyzed by Western blotting. OD-band intensities of COX-2 and phospho-proteins, analyzed by Odyssey ${ }^{\mathbb{B}}$ software, were normalized to the respective loading control protein and expressed in relation to the maximum band intensity of the MAF02-treated sample (100\%). To detect mobilization of AA and its metabolites (C, E), RAW264.7 macrophages labelled with $\left[{ }^{14} \mathrm{C}\right]$ arachidonic acid were pre-incubated with the antioxidant NAC at 1 or $5 \mathrm{mM}$ and subsequently exposed with $50 \mathrm{\mu g} / \mathrm{ml}$ MAF02 particles $\left(13.2 \mu \mathrm{g} / \mathrm{m}^{2}\right)$ for 2.5 hours. After lipid extraction, the free arachidonic acid and its metabolites were separated by TLC, visualized by autoradiography and analyzed by OptiQuant ${ }^{\circledR}$ software. Data on AA liberation are expressed as percentage of control cells (100\% values). Results are presented as the mean \pm s.e.m. of three independent experiments $\left({ }^{*} p<0.05\right.$, ${ }^{* *} p<0.01$, ${ }^{* * *} \mathrm{p}<0.001$ compared to $50 \mu \mathrm{g} / \mathrm{ml}$ MAF02-treated cells). 

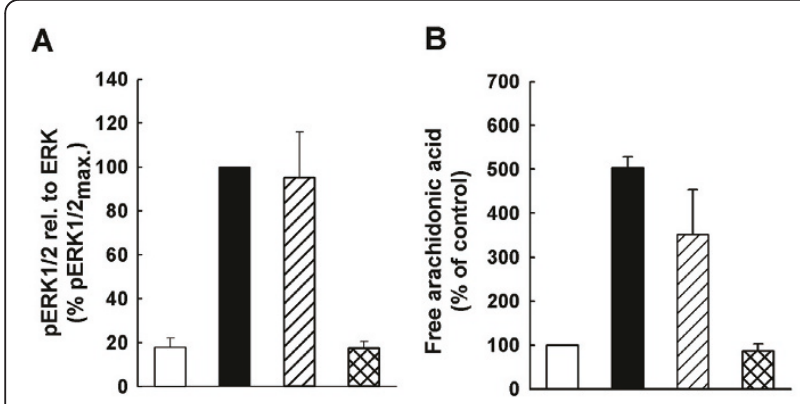

C

\section{D}
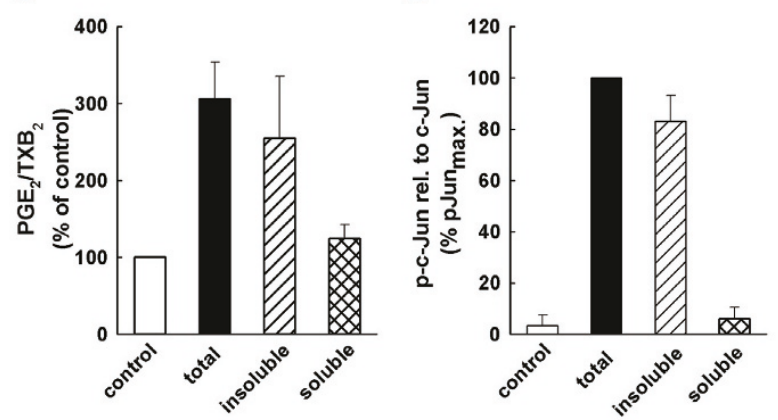

Figure 7 The water-insoluble fraction of MAF02 is responsible for AA mobilization and activation of ERK1/2 and c-Jun. For analysis of ERK1/2 (A), and c-Jun (D) phosphorylation non-labelled cells were exposed with $50 \mathrm{\mu g} / \mathrm{ml}\left(15.6 \mu \mathrm{g} / \mathrm{m}^{2}\right)$ of the total, watersoluble and water-insoluble fraction of fly ash particles for 2.5 hours. Whole cell lysates were analyzed by Western blotting. OD-band intensities of phosphorylated proteins, analyzed by Odyssey ${ }^{\circledR}$ software, were normalized to the respective loading control protein and expressed in relation to the maximum band intensity of the MAF02-treated sample (100\%). (B, C) RAW264.7 cells labelled with $\left[{ }^{14} \mathrm{C}\right]$ arachidonic acid were treated with $50 \mu \mathrm{g} / \mathrm{ml}\left(13.2 \mu \mathrm{g} / \mathrm{m}^{2}\right)$ of the total, water-insoluble and water-soluble fraction of fly ash particles for 2.5 hours. After lipid extraction, the free arachidonic acid and its metabolites were separated by TLC, visualized by autoradiography and analyzed by OptiQuant ${ }^{\circledR}$ and Odyssey ${ }^{\circledR}$ software. Data on AA liberation are expressed as percentage of control cells (100\% values). Results are presented as the mean \pm s.e.m. of three independent experiments.

to lipid mediators are relevant in initiation, maintenance and resolution of inflammation and therefore play a significant role in chronic inflammation. Furthermore, disturbed regulation of AA metabolism may contribute to cancer diseases in particular those of the lung [20-22].

The fly ash particles induced a strong mobilization of AA at non-cytotoxic concentrations. For similar metalladen combustion-derived particles such as residual oil fly ash (ROFA) the influence of lipid mediators in mediating pulmonary toxicity has been shown in vivo and in vitro [41] pointing to deregulated lipid mediators as a central toxicity pathway.

Human monocyte-derived macrophages (MDM) were tested for their response to MAF02, however we only observed a 1.8-fold increase of AA liberation after
5 hours exposure in comparison to a 6-fold increase in RAW264.7 macrophages. The lower expression of cPLA $_{2}$ in MDM compared to RAW264.7 cells may be a reason for their reduced potential to induce AA mobilization (data not shown). Alternatively, human macrophages might be less susceptible to PM-induced AA liberation, a possibility which needs to be further investigated. Although the AA mobilization after MAF02 treatment was not as pronounced as in RAW264.7 macrophages, the increase in ROS and MAPK activity as well as the reduction in viability after exposure to MAF02 was quite comparable to the effects observed in RAW264.7 cells. Therefore, it seems that the signalling cascades induced by fly ash particles in RAW264.7 cells are conserved in primary human macrophages.

The mobilized arachidonic acid may be further metabolized by cyclooxygenases (COX) to biologically active mediators such as leukotrienes, prostaglandins and thromboxanes, which play a role during inflammatory processes. Here we demonstrate that MAF02-induced COX-2 is also catalytically active since the level of the metabolites $\mathrm{PGE}_{2} / \mathrm{TXB}_{2}$ in the supernatant increased in a time-dependent manner. Particle-induced induction of COX-2 as well as release of $\mathrm{PGE}_{2}$ by immunecompetent cells has also been shown in other studies $[18,42-44]$. The consequences of increased $\mathrm{PGE}_{2}$ release cannot be predicted directly since it regulates proinflammatory as well as anti-inflammatory effects. The action of $\mathrm{PGE}_{2}$ is dependent on the presence or absence of $\mathrm{PGE}_{2}$ receptors EP1 - EP4 on the target cells. $\mathrm{PGE}_{2}$ has therefore the ability to switch from pro-inflammatory to anti-inflammatory mechanisms. Anti-inflammatory effects have been shown in human monocytes where $\mathrm{PGE}_{2}$ down-regulated TNF- $\alpha$ induced expression of ICAM-1 by interaction with EP2 and EP4 [45]. In contrary, interaction with EP1 and EP3 induced proinflammatory effects. Beck-Speier et al. [46] suggest, that $\mathrm{PGE}_{2}$ released due to fine $\mathrm{TiO}_{2}$ particles with low surface area may act anti-inflammatory in that it down-regulates particle-induced inflammatory effects. However, $\mathrm{PGE}_{2}$ released due to ultrafine $\mathrm{TiO}_{2}$ particles with large surface area may act proinflammatory since the inflammatory mediator leukotriene $\mathrm{B}_{4}$ as well as release of 8 -isoprostane were also induced. The basis for these size-dependent differences remains to be clarified.

MAF02 exposure induced enhanced ROS levels as measured by the DCF assay. However, as the DCF assay sometimes produces false positive results [47] we analysed previously additional markers of oxidative stress e.g. HO-1 induction and increase of GSH synthesis $[13,17]$. In addition, in the present study we also detected a significant release of 8 -isoprostane, which further demonstrates the high oxidative potential of the particles on cell membranes. 8-isoprostane, however, has 


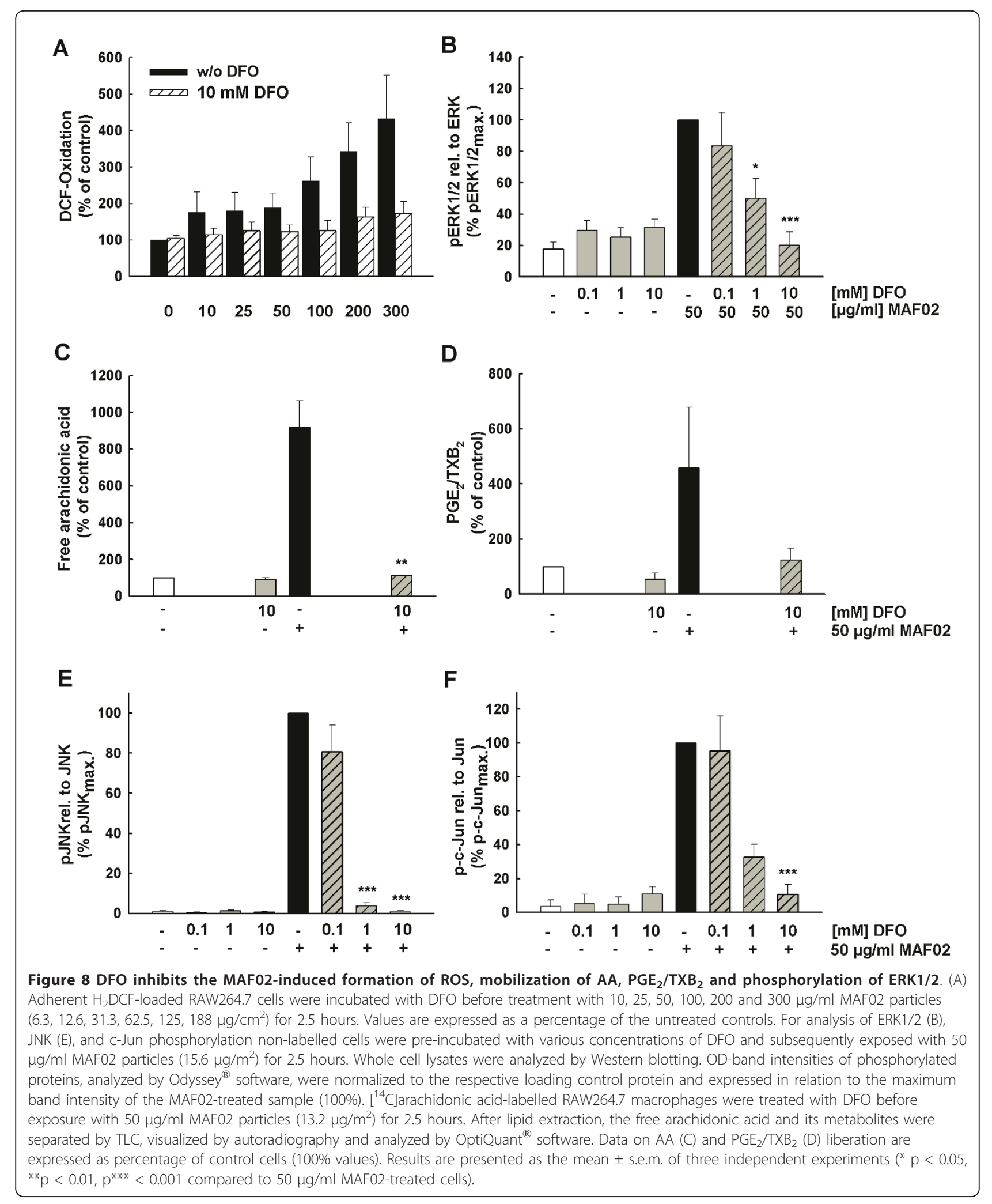


numerous biologic effects, e.g. it is a potent vasoconstrictor, causes contraction of bronchial smooth muscle and induces exudation in the airways $[48,49]$. Therefore, the enhanced formation of disease-related 8-isoprostane can contribute to the adverse health effects of particulate matter.

In most cases, the cause of AA mobilization and generation of AA-derived lipid mediators is the activation of phospholipase $A_{2}$ which catalyzes the deacylation of AA from the sn-2 position of membrane glycerophospholipids. In this study we demonstrated that the MAF02-induced AA mobilization is mainly mediated by the $\mathrm{Ca}^{2+}$-dependent $\mathrm{CPLA}_{2}$, not by $\mathrm{iPLA}_{2}$ and $\mathrm{sPLA}_{2}$. This is supported by the finding that MAF02-induced AA mobilization is inhibited by the intracellular calcium chelator BAPTA/AM [17] as well as by the extracellular calcium chelator EGTA (data not shown). An elevated intracellular $\mathrm{Ca}^{2+}$ concentration is necessary for the translocation of the activated cPLA $_{2}$ to its target structure in perinuclear membranes [50]. Stone and colleagues [51] observed an increase of the intracellular $\mathrm{Ca}^{2}$ ${ }^{+}$-concentration in the human Mono Mac 6 cell line after exposure to ultrafine carbon black particles, which could also be inhibited by EGTA as well as by the calcium channel blocker verapamil. The authors suggest that ROS triggers an opening of the $\mathrm{Ca}^{2+}$-channels which lead to a flux from the extracellular compartment into the cytosol $[51,52]$.

In MAF02-treated cells cPLA 2 was phosphorylated which is required for activation of the enzyme. The time course of phosphorylation was in accordance with the MAF02-induced AA mobilization and could be reduced by inhibition of the ERK1/2 and p38 MAPKs. Activation of CPLA $_{2}$ by phosphorylation via the ERK $1 / 2$ and the p38 MAPK signalling pathways has already been described [50]. Using phospho-specific antibodies we found in this study that ERK $1 / 2$ and JNK1/2 were phosphorylated after treatment of RAW264.7 macrophages and MDM with MAF02 particles with similar kinetic compared to the mobilization of AA whereas $\mathrm{p} 38$ MAPK was only weakly phosphorylated. Thus MAPKs activity is not only required to activate the $\mathrm{CPLA}_{2}$ and mobilize AA but is also induced in response to MAF02. Similar results were found in primary canine alveolar macrophages which were exposed to diesel exhaust particles. Inhibitor studies indicated an involvement of ERK1/2 but not of p38 MAPK in the DEP-induced mobilization of AA and synthesis of its metabolites $\mathrm{PGE}_{2}$ and $\mathrm{LTB}_{4}$ [18].

The results so far indicate an involvement of ROS and oxidative stress in the cellular responses to the fly ash particles. To demonstrate involvement of ROS in the AA metabolism we used the antioxidant NAC, a general antioxidant but also a metal-binding agent [53]. NAC has been used as a tool for investigating the role of ROS in numerous biological and pathological processes [54]. We could show that pre-treatment of RAW264.7 macrophages with $5 \mathrm{mM}$ NAC resulted in significant inhibition of fly ash-induced phosphorylation of ERK1/2, mobilization of AA, and induced expression of COX-2. This clearly demonstrates a contribution of ROS and possibly metals in these mechanisms. While pre-incubation of the cells with $1 \mathrm{mM}$ NAC had no or only a weak effect on these responses, surprisingly the MAF02-induced phosphorylation of JNK1/2 as well as of c-Jun was completely inhibited at this low NAC concentration. This means that the activation of the JNK1/2 signalling pathway is, although ROS dependent, probably not involved in the mechanisms of MAF02-induced mobilization of AA, and expression of COX-2, at least in RAW264.7 macrophages. In accordance with this hypothesis, the specific inhibitor of the JNK1/2 pathway SP600125 did not prevent AA mobilization and COX induction by MAF02 thus demonstrating that indeed the JNK cascade is not involved in this response.

The mechanisms by which endogenously produced ROS or metals activate MAP kinases are not well defined. One possible explanation is the regulation of the MAPK activity by protein phosphatases, which are known to be sensitive to ROS and metals because of their cysteinyl thiol groups in their active site $[11,55,56]$.

The fly ash used in this study has a high content of water-soluble material ( $61 \%$ by weight) which has been shown to be biologically inactive in our assays. This is contrary to other studies with complex material such as ambient particulate matter where water-soluble metals were shown to be associated with induction of ROS, oxidative stress and pro-inflammatory effects [33]. Although transition metals such as $\mathrm{Fe}$ and $\mathrm{Zn}$ are significant components of the MAF02 fly ash, the water-soluble portion of these metals may be too low-concentrated to catalyze the formation of ROS via a Fenton-like reaction [32,57-59]. The insoluble fraction still contains metals in a glass-like matrix and those metals on the surface may become soluble intracellularly and thereby responsible for the observed effects. The metal chelator DFO prevented entirely ROS formation and downstream signalling suggesting a critical role of metals in the inflammatory response triggered by MAF02. Thus, in the absence of transition metals the remaining particulate fraction is inactive and does not trigger inflammation mediated by AA. The relevance of biologically available transition metals in particular iron in inducing adverse effects has been demonstrated for air pollution particles [60], asbestos [61], and carbon nanotubes [62]. 


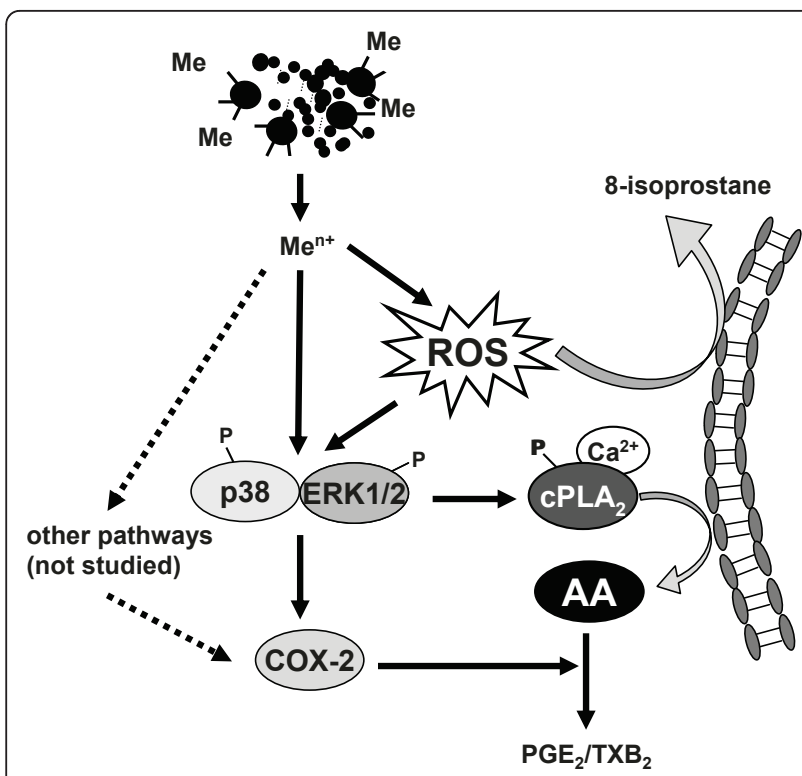

Figure 9 Scheme of the MAF02-induced activation of the arachidonic acid cascade. The MAF02 particles are taken up by RAW264.7 macrophages and release metal ions $\left(\mathrm{Me}^{\mathrm{n}+}\right)$ inside the cells which induces formation of reactive oxygen species (ROS). Release of 8-isoprostane indicates the occurrence of oxidative stress. Oxidative stress in turn leads to activation of the ERK1/2 and p38 pathways. The ERK1/2 pathway may be activated by interfering of the particles with membrane proteins. On the other hand, enhanced MAPK activation can also occur by inhibition of metal- and redoxsensitive phosphatases, which dephosphorylate and inactivate MAPK. Activation of ERK1/2 and p38 leads to phosphorylation and activation of $C P L A_{2}$ (cytosolic phospholipase $A_{2}$ ). The increase of the intracellular calcium level induces $C P L A_{2}$ translocation to the perinuclear membranes where it catalyzes the mobilization of AA. On the other hand, it is possible that ROS inhibit the reacylation of AA, which would also lead to an enhanced level of free AA in the cytosol. Free AA is converted by COX-2 (cyclooxygenase-2) and prostaglandin synthases to $P G E_{2} / T_{X B_{2}}$ (prostaglandin $E_{2} /$ thromboxane $B_{2}$ ). Increased transcription of COX-2 requires activation of ERK $1 / 2$ and $\mathrm{p} 38$, but may also involve other pathways e.g. NF- $\kappa$ B.

On the basis of the data obtained from the present and the previous study we suggest the following mechanism (Figure 9):

The MAF02 particles are taken up by RAW264.7 macrophages and induce a metal-mediated generation of reactive oxygen species. Furthermore, release of 8 -isoprostane, increased synthesis of glutathione and induction of heme oxygenase-1 [17] indicate significant oxidative stress due to particle exposure resulting in an anti-oxidative cellular response. Oxidative stress leads to activation of the ERK1/2 pathway including MEK1/2, JNK1/2 and p38 MAP kinases. The ERK1/2 pathway may be activated by interference of the particles with membrane proteins such as growth factor receptors. Growth factor receptors and MAPK can also be stimulated by inhibition of phosphatases, which are metaland redox-sensitive enzymes.
Active ERK1/2 and p38 leads to phosphorylation and activation of $\mathrm{CPLA}_{2}$. The increase of the intracellular calcium level induces the $\mathrm{CPLA}_{2}$ to translocate to the perinuclear membranes where it catalyzes the mobilization of AA. In addition, it is possible that ROS inhibit the reacylation of AA, which would also lead to an enhanced level of free AA in the cytosol. Free AA serves as substrate for $\mathrm{COX}-2$ and prostaglandin synthases leading to the release of $\mathrm{PGE}_{2}$. Increased transcription of COX-2 requires activation of ERK $1 / 2$ and $\mathrm{p} 38$, but may also involve other pathways e.g. NF- $\kappa \mathrm{B}$ [63].

\section{Conclusions}

In summary, the results of the present study suggest, that exposure of macrophages to fly ash particles promotes inflammation by liberation of arachidonic acid and metabolization to related products such as $\mathrm{PGE}_{2}$ / $\mathrm{TXB}_{2}$ via metal-induced formation of ROS and induction of cellular oxidative stress.

The fly ash-induced processes such as formation of ROS, activation of ERK1/2, JNK1/2 and p38 MAPK pathways were also observed in primary human MDM, however mobilization of AA was less severe possibly because of the incomplete differentiation to macrophages.

The postulated mechanism may therefore also be relevant in humans, where it may contribute to lung diseases such as chronic inflammation after acute or chronic exposure to fine and ultrafine particulate matter.

\section{Methods \\ Materials}

Cell culture medium and supplements, Hank's balanced salt solution (HBSS) and 2',7'-dichlorodihydrofluorescein-diacetate $\left(\mathrm{H}_{2} \mathrm{DCF}-\mathrm{DA}\right)$ were obtained from Invitrogen (Karlsruhe, Germany). Accutase was from PAA (Cölbe, Germany). The WST-1 reagent was from Roche (Mannheim, Germany) and the SDS-PAGE supplies were from Carl Roth (Karlsruhe, Germany). $\left[1-{ }^{14} \mathrm{C}\right]$ arachidonic acid $(2.07 \mathrm{GBq} / \mathrm{mmol})$ and ECL reagents were purchased from GE Healthcare (Freiburg, Germany). Chemicals for lipid extraction and chromatography were from VWR International (Bruchsal, Germany). The $\mathrm{PLA}_{2}$ inhibitors thioetheramide phosphatidylcholine (TEA-PC), arachidonyl trifluoromethyl ketone $\left(\mathrm{AACOCF}_{3}\right)$, and bromoenol lactone (BEL) were from Cayman (Biozol, Eching, Germany). MAPK inhibitors, PD98059 (2'-amino-3'-methoxyflavone), SB203580 [4-(4fluorophenyl)-2-(4-methylsulfinylphenyl)-5-(4-pyridyl) $1 \mathrm{H}$-imidazole], and SP600125 (1,9-pyrazoloanthrone) were purchased from Merck (Darmstadt, Germany). Nacetyl-cysteine (NAC), deferoxamine mesylate (DFO) and standard laboratory chemicals were supplied by Sigma-Aldrich (Taufkirchen, Germany). The human 
recombinant granulocyte-macrophage colony-stimulating factor (GM-CSF) was from VWR, Bruchsal, Germany.

Specific anti-phospho ERK1/2 $\left(\mathrm{Tyr}^{202} / \mathrm{Tyr}^{204}\right)$, antiphospho p38 ( Tyr $^{180} / \mathrm{Tyr}^{182}$ ), anti-phospho JNK1/2 $\left(\mathrm{Tyr}^{183} / \mathrm{Tyr}^{185}\right)$, anti-phospho c-Jun, anti-phospho MEK1/2, anti-phospho cPLA $2\left(\operatorname{Ser}^{505}\right)$, and anti-c-Jun were obtained from Cell Signaling (New England Biolabs, Frankfurt, Germany). Anti-ERK1/2, anti-p38, antiJNK, anti-cPLA 2 , anti-LaminB, and anti-PCNA were from Santa Cruz (Heidelberg, Germany). Anti-COX-1 and anti-COX-2 were from Biozol (Eching, Germany). Horseradish peroxidase (HRP)-conjugated secondary anti-rabbit antibodies were from GE Healthcare, Braunschweig, Germany and anti-mouse antibodies from DAKO (Hamburg, Germany). IRDye700 or IRDye800 coupled secondary antibodies were obtained from Biomol (Hamburg, Germany).

\section{Particles}

The fly ash MAF02 originates from a municipal waste incinerator facility and was collected in 2002 by electrostatic precipitation in the exhaust gas cleaning system. Subsequently, the powder was size-fractionated to remove particles $>20 \mu \mathrm{m}$. The remaining fine fraction $(<20 \mu \mathrm{m})$ has been used for the in vitro experiments. Analysis of the particle size distribution by scanning mobility particle sizing (SMPS, DMA 3071 with CPC 3022A, TSI Inc., Shoreview, USA) after resuspension in air showed that the number concentration was dominated by fine and ultrafine particles with a modal value of $165 \mathrm{~nm}$ [13]. Additional analyses using the light-scattering spectrometer PCS-2000 (Palas, Karlsruhe, Germany) and scanning electronic microscopy (SEM) of particles deposited on a Nuclepore ${ }^{\mathrm{TM}}$ Polycarbonate Membrane (pore size 0.4 $\mu \mathrm{m}$, Whatman, Dassel, Germany) confirmed the low percentage of large agglomerates (Figure 1A-B).

Elemental analysis was performed with total particles as well as with the water-soluble and insoluble fraction. For the separation $1 \mathrm{~g}$ of particles was extracted twofold with $25 \mathrm{ml}$ of deionized water. The aqueous suspensions were probe sonified (Branson Sonifier 250, Heinemann, Schwäbisch-Gmünd, Germany) for $20 \mathrm{~s}$ (duty cycle 40, output control 4) and centrifuged at $1000 \mathrm{~g}$ for $30 \mathrm{~min}$. The combined aqueous supernatants as well as the dried pellet were analyzed by Total Reflection X-ray Fluorescence Analysis (TRFA). As and Cd were measured by Inductively Coupled Plasma - Optical Emission Spectrometry (ICP-OES). The fraction of elemental carbon was determined by combustion of the material in a copper tube at $950^{\circ} \mathrm{C}$ and measuring the $\mathrm{CO}$ concentration.
For cell experiments stock suspensions of $10 \mathrm{mg} / \mathrm{ml}$ in culture medium without FBS were prepared freshly and dispersed by vortexing and probe sonication for $20 \mathrm{~s}$. Working suspensions were prepared by further dilution in culture medium. The particles were tested for endotoxin content with the colorimetric Limulus Amebocyte Lysate (LAL) assay (Lonza, Basel, Switzerland). A particle suspension of $1 \mathrm{mg} / \mathrm{ml}$ in water was centrifuged for $10 \mathrm{~min}$ at 20,800 $\mathrm{g}$ and the supernatant was analyzed according to the instructions of the manufacturer. The result was below the lower limit of quantification of the test $(<0.1 \mathrm{EU} / \mathrm{ml})$.

\section{Cell culture}

The murine RAW264.7 macrophage cell line was obtained from the American Type Culture Collection (ATCC Rockville, MD, USA). The cells were cultured in DMEM supplemented with $10 \%$ fetal bovine serum (FBS), $100 \mathrm{U} / \mathrm{ml}$ penicillin and $100 \mu \mathrm{g} / \mathrm{ml}$ streptomycin in $5 \% \mathrm{CO}_{2}$ at $37^{\circ} \mathrm{C}$. They were passaged every 3 to 4 days by scraping off the cells from the culture plate. To investigate AA release and intracellular signalling pathways, cells were seeded onto 12 -well plates at $3 \times 10^{5}$ cells/well or into 6 -well plates at $2.5 \times 10^{6}$ cells/well. After adhering overnight, the cells were cultured for another day in serum-free medium prior to stimulation. All inhibitors were added $30 \mathrm{~min}$ prior to stimulation at the indicated concentrations.

\section{Generation of human monocyte-derived macrophages (MDM)}

Human peripheral blood mononuclear cells (PBMC) were isolated from buffy coats derived from healthy donors (Städtisches Klinikum Karlsruhe) by Ficoll density gradient centrifugation (Ficoll-Paque ${ }^{\mathrm{TM}}$ Premium, GE Healthcare, Freiburg). For isolation of CD14-positive monocytes, the MACS magnetic separation technique (Miltenyi Biotec, Bergisch-Gladbach, Germany) was used according to the manufacturer's protocol. Briefly, $1 \times$ $10^{7}$ PBMC suspended in $80 \mu$ l of MACS buffer (phosphate-buffered saline (PBS) containing $0.5 \%$ BSA and 2 $\mathrm{mM}$ EDTA) were mixed with $20 \mu \mathrm{l}$ of anti-CD14 microBeads and incubated at $4^{\circ} \mathrm{C}$ for $15 \mathrm{~min}$. The cells were washed with $2 \mathrm{ml}$ MACS buffer, resuspended in $500 \mu \mathrm{l}$ fresh MACS buffer and loaded onto a separation column which was positioned in a MidiMACS magnet. Non-adherent cells were washed out and after removal from the magnet the CD14-positive cells were recovered from the column by pressing $5 \mathrm{ml}$ of MACS buffer through the column.

The percentage of the purified monocytes was determined by flow cytometry (LSR II with CellQuest PRO software, Becton Dickinson, Heidelberg, Germany) using 
FITC-labeled anti-CD14 antibodies (My4-FITC, Coulter, Krefeld, Germany) and FITC-labelled anti-IgG2a antibodies (Miltenyi Biotec, Bergisch Gladbach, Germany) as isotype control. The cells were detected with an excitation wavelength of $488 \mathrm{~nm}$ and an emission wavelength at $530 \mathrm{~nm}$. The purity of the preparation was determined to be $89.4 \pm 1.2 \%(n=4)$ of CD14-positive monocytes after the cell separation from different donors. The remaining $9-11 \%$ cells were lymphocytes, which were not further analyzed.

The isolated cells were resuspended in RPMI 1640 medium supplemented with 1\% MEM non-essential amino acids, $1 \%$ pyruvate, $4 \% \mathrm{FBS}, 100 \mathrm{U} / \mathrm{ml}$ penicillin, $100 \mu \mathrm{g} / \mathrm{ml}$ streptomycin, $2 \mathrm{mM}$ glutamine and $2 \mathrm{ng} / \mathrm{ml}$ GM-CSF at $1 \times 10^{6}$ cells $/ \mathrm{ml}$ and cultivated in $5 \% \mathrm{CO}_{2}$ at $37^{\circ} \mathrm{C}$ for 10 days. Medium was changed every 3 to 4 days. Before the experiments, the MDM were detached from the surface using accutase and seeded into 96-well plates at $2 \times 10^{5}$ cells/well, into 12 -well plates at $3 \times$ $10^{5}$ cells/well or into 6 -well plates at $2.5 \times 10^{6}$ cells/well.

\section{Transmission electron microscopy (TEM)}

To determine the time-dependent uptake of particles RAW264.7 macrophages were grown on Transwell ${ }^{\circledR}$ inserts with polycarbonate membranes with $0.4 \mu \mathrm{m}$ pores (Corning, Wiesbaden, Germany) and exposed to particle suspensions at $50 \mu \mathrm{g} / \mathrm{ml}\left(10.4 \mu \mathrm{g} / \mathrm{cm}^{2}\right)$. Pieces of the membrane with the adherent cells were cut out and fixed in Karnovsky's fixant containing 2.5\% glutaraldehyde $(\mathrm{w} / \mathrm{v})$ for $15 \mathrm{~min}$. The membranes were washed with PBS, post-fixed in $1 \%(\mathrm{w} / \mathrm{v})$ osmium tetroxide for 7 min and dehydrated in a graded series of ethanol (50, 70, 95, and 100\%). Afterwards the membranes were embedded in EPON 812 (Polysciences, Eppelheim, Germany). The blocks were cutted into ultrathin sections using a UC6 ultramicrotome (Leica, Bensheim, Germany). Images were taken with a Zeiss EM 109T transmission electron microscope (Oberkochen, Germany).

\section{Viability assay}

Cell viability was determined in 96 -well plates by the WST-1 assay after treatment with the particles suspended in complete medium at the indicated concentrations for $24 \mathrm{~h}$. The medium was replaced by $100 \mu \mathrm{l}$ WST-1 reagent diluted 1:20 (v/v) with HBSS. After incubation at $37^{\circ} \mathrm{C}$ and $5 \% \mathrm{CO}_{2}$ for $2 \mathrm{~h}$ the activity of mitochondrial dehydrogenases was detected with a microplate reader (Molecular Devices, Ismaning, Germany) at $450 \mathrm{~nm}$.

\section{Intracellular ROS detection}

Macrophages seeded in 96-well plates were treated with particles suspended in HBSS for $3 \mathrm{~h}$ at the doses indicated (Figure 2B). After washing with HBSS, the cells were loaded with $50 \mu \mathrm{M} \mathrm{H} \mathrm{H}_{2}$ DCF-DA for $30 \mathrm{~min}$. Subsequently, the cells were washed again with HBSS and the relative fluorescence units were determined at $485 \mathrm{~nm}$ excitation and $530 \mathrm{~nm}$ emission wavelengths using a fluorescence reader (MWG-Biotech AG, Ebersberg, Germany). Alternatively, the cells were loaded with $50 \mu \mathrm{M}$ $\mathrm{H}_{2}$ DCF-DA for 30 min prior to the particle incubation to improve sensitivity (Figure 8 ). After treatment with particles for $2.5 \mathrm{~h}$, the cell layer was washed with HBSS and the relative fluorescence units were detected.

\section{Analysis of arachidonic acid and $\mathrm{PGE}_{2} / \mathrm{TXB}_{2}$ liberation}

The determination of arachidonic acid and $\mathrm{PGE}_{2} / \mathrm{TXB}_{2}$ liberation in macrophages was performed as described before [17]. Briefly, after labelling with $\left[1-{ }^{14} \mathrm{C}\right]$ arachidonic acid the cells were treated with particles for the indicated periods of time in medium without FBS. The cellular lipids were extracted with a mixture of chloroform, methanol and $0.2 \%$ formic acid in water according to a modified procedure originally described by Bligh and Dyer [64]. The organic phase was collected, dried under nitrogen, and dissolved with $100 \mu \mathrm{l}$ chloroform. The extract was spotted onto $0.25 \mathrm{~mm}$ silica gel HPTLC plates (Macherey-Nagel, Düren, Germany) and separated by thin-layer chromatography using the solvent system of ethyl acetate : iso-octane : $\mathrm{H}_{2} \mathrm{O}$ : acetic acid at 10:5:10:2 (v:v:v:v). The location of $\left[{ }^{14} \mathrm{C}\right]$-labelled arachidonic acid and its metabolites was visualized and quantified using the phosphoimager system Cyclone ${ }^{\circledR}$ Plus equipped with the software OptiQuant Acquisition and Analysis (Perkin Elmer, Rodgau-Jügesheim, Germany). To identify the spots of free arachidonic acid and its metabolites, non-radioactive standards were run in the same solvent system and visualized by exposing the plates to $10 \%$ phosphomolybdic acid in ethanol. Since $\mathrm{PGE}_{2}$ and $\mathrm{TXB}_{2}$ showed equal retention factor (Rf) values under these conditions, these metabolites were quantified as a single spot.

\section{Detection of 8-isoprostane}

After treatment of cells the medium was collected, centrifuged for $5 \mathrm{~min}$ at $4^{\circ} \mathrm{C}$ and $13,000 \times$ g to remove cell debris and stored at $-80^{\circ} \mathrm{C}$ until analysis. 8-isoprostane was analyzed by a competitive enzyme immunoassay (EIA) according to the instructions of the manufacturer (Cayman, distributed by Biozol, Eching, Germany).

\section{Western blotting}

Cells were harvested, washed twice with PBS and lysed for $20 \mathrm{~min}$ at $4^{\circ} \mathrm{C}$ in $75 \mu \mathrm{l}$ RIPA lysis buffer $(150 \mathrm{mM}$ $\mathrm{NaCl}, 50 \mathrm{mM}$ Tris- $\mathrm{HCl} \mathrm{pH}$ 7.4, 5 mM EDTA, 1\% (v/v) NP-40, $2 \mu \mathrm{g} / \mathrm{ml}$ leupeptin, $2 \mu \mathrm{g} / \mathrm{ml}$ aprotinine, $1 \mathrm{mM}$ PMSF). For the detection of phosphorylated proteins, the lysis buffer additionally contained phosphatase 
inhibitor cocktail 1 and 2 (Sigma, Taufkirchen, Germany). The cell lysates were centrifuged at $12,000 \mathrm{~g}$ for $5 \mathrm{~min}$ at $4^{\circ} \mathrm{C}$ and the protein contents of the supernatants were measured with the BCA assay using BSA as a standard (Perbio, Bonn, Germany). Equivalent amounts of protein were loaded on a $10 \%$ sodium dodecyl sulphate (SDS)-polyacrylamide gel. After electrophoresis, the proteins were transferred to an Immobilon-FL or Immobilon-P PVDF membrane (Millipore, Eschborn, Germany). The membranes were blocked with $5 \%(\mathrm{w} / \mathrm{v})$ non-fat dry milk in Tris-buffered saline (TBS) for $1 \mathrm{~h}$ and then incubated overnight at $4^{\circ} \mathrm{C}$ with the appropriate primary antibody in 5\% non-fat dry milk in TBS containing $0.1 \%$ Tween 20 (TBS-T). After washing, the membranes were either incubated with a secondary antibody coupled with horseradish peroxidase for detection with ECL reagents or to IRDye800 or Alexa680 coupled secondary antibodies for detection with the Odyssey Infrared Imaging System (LICOR Biosciences, Bad Homburg, Germany). The procedures for detection with ECL and the Odyssey method were performed in accordance with the manufacturer's instructions.

\section{Statistical analysis}

Values are reported as mean \pm standard error of the mean (s.e.m.) of several independent experiments as indicated in the legends. Statistical analysis was performed using Student's $t$ test. Values of $\mathrm{p}<0.05$ were considered statistically significant.

\section{Acknowledgements}

The authors thank Manuela Hauser for the scanning electron microscopy of the MAF02 fly ash as well as Britta Bergfeldt for the elemental analyses. Funding for this study was provided by the Federal Institute for Risk Assessment (BfR), Germany, (BfR-ZEBET-1238-182).

\section{Author details}

${ }^{1}$ Karlsruhe Institute of Technology, Campus North, Institute of Toxicology and Genetics, Hermann-von-Helmholtz-Platz 1, 76344 EggensteinLeopoldshafen, Germany. ${ }^{2}$ Karlsruhe Institute of Technology, Campus North, Institute of Technical Chemistry, Hermann-von-Helmholtz-Platz 1, 76344 Eggenstein-Leopoldshafen, Germany.

\section{Authors' contributions}

SFD, CW and SD conceived and designed the experiments. SFD and TB performed the experiments and analyzed the data. SM provided the MAF02 fly ash and analyzed the particle size distribution and both, SM and HRP contributed to discuss the particle data. SFD wrote the manuscript with assistance of CW and SD. All authors read and approved the final manuscript.

\section{Competing interests}

The authors declare that they have no competing interests.

Received: 1 December 2010 Accepted: 2 August 2011

Published: 2 August 2011

\section{References}

1. Dockery DW, Luttmann-Gibson H, Rich DQ, Link MS, Mittleman MA, Gold DR, Koutrakis P, Schwartz JD, Verrier RL: Association of air pollution with increased incidence of ventricular tachyarrhythmias recorded by implanted cardioverter defibrillators. Environ Health Perspect 2005, 113:670-674.

2. Pope CA III, Burnett RT, Thurston GD, Thun MJ, Calle EE, Krewski D, Godleski JJ: Cardiovascular mortality and long-term exposure to particulate air pollution: epidemiological evidence of general pathophysiological pathways of disease. Circulation 2004, 109:71-77.

3. Alessandrini F, Beck-Speier I, Krappmann D, Weichenmeier I, Takenaka S, Karg E, Kloo B, Schulz H, Jakob T, Mempel M, et al: Role of oxidative stress in ultrafine particle-induced exacerbation of allergic lung inflammation. Am J Respir Crit Care Med 2009, 179:984-991.

4. Pope CA, Muhlestein JB, May HT, Renlund DG, Anderson JL, Horne BD: Ischemic heart disease events triggered by short-term exposure to fine particulate air pollution. Circulation 2006, 114:2443-2448.

5. Woodruff TJ, Parker JD, Schoendorf KC: Fine particulate matter (PM2.5) air pollution and selected causes of postneonatal infant mortality in California. Environ Health Perspect 2006, 114:786-790.

6. Zanobetti A, Canner MJ, Stone PH, Schwartz J, Sher D, Eagan-Bengston E, Gates KA, Hartley LH, Suh H, Gold DR: Ambient pollution and blood pressure in cardiac rehabilitation patients. Circulation 2004, 110:2184-2189.

7. Behndig AF, Mudway IS, Brown JL, Stenfors N, Helleday R, Duggan ST, Wilson SJ, Boman C, Cassee FR, Frew AJ, et al: Airway antioxidant and inflammatory responses to diesel exhaust exposure in healthy humans. Eur Respir J 2006, 27:359-365.

8. Schaumann F, Borm PJ, Herbrich A, Knoch J, Pitz M, Schins RP, Luettig B, Hohlfeld JM, Heinrich J, Krug N: Metal-rich ambient particles (particulate matter 2.5) cause airway inflammation in healthy subjects. Am J Respir Crit Care Med 2004, 170:898-903.

9. Stenfors N, Nordenhall C, Salvi SS, Mudway I, Soderberg M, Blomberg A, Helleday R, Levin JO, Holgate ST, Kelly FJ, et al: Different airway inflammatory responses in asthmatic and healthy humans exposed to diesel. Eur Respir J 2004, 23:82-86.

10. Marano F, Hussain S, Rodrigues-Lima F, Baeza-Squiban A, Boland S: Nanoparticles: molecular targets and cell signalling. Arch Toxicol 2010.

11. Kamata H, Honda S, Maeda S, Chang L, Hirata H, Karin M: Reactive oxygen species promote TNFalpha-induced death and sustained JNK activation by inhibiting MAP kinase phosphatases. Cell 2005, 120:649-661.

12. Rahman I, Adcock IM: Oxidative stress and redox regulation of lung inflammation in COPD. Eur Respir J 2006, 28:219-242.

13. Diabaté S, Mülhopt S, Paur HR, Krug HF: The response of a co-culture lung model to fine and ultrafine particles of incinerator fly ash at the airliquid interface. Altern Lab Anim 2008, 36:285-298.

14. Haberzettl P, Duffin R, Kramer U, Hohr D, Schins RP, Borm PJ, Albrecht C Actin plays a crucial role in the phagocytosis and biological response to respirable quartz particles in macrophages. Arch Toxicol 2007, 81:459-470.

15. Wottrich R, Diabaté S, Krug HF: Biological effects of ultrafine model particles in human macrophages and epithelial cells in mono- and coculture. Int J Hyg Environ Health 2004, 207:353-361.

16. Singh S, Shi T, Duffin R, Albrecht C, van Berlo D, Hohr D, Fubini B, Martra G, Fenoglio I, Borm PJ, et al: Endocytosis, oxidative stress and IL-8 expression in human lung epithelial cells upon treatment with fine and ultrafine TiO2: role of the specific surface area and of surface methylation of the particles. Toxicol Appl Pharmacol 2007, 222:141-151.

17. Fritsch S, Diabaté S, Krug HF: Incinerator fly ash provokes alteration of redox equilibrium and liberation of arachidonic acid in vitro. Biol Chem 2006, 387:1421-1428.

18. Beck-Speier I, Dayal N, Karg E, Maier KL, Schumann G, Schulz H, Semmler M, Takenaka S, Stettmaier K, Bors W, et al: Oxidative stress and lipid mediators induced in alveolar macrophages by ultrafine particles. Free Radic Biol Med 2005, 38:1080-1092.

19. Hofer TP, Bitterle E, Beck-Speier I, Maier KL, Frankenberger M, Heyder J, Ziegler-Heitbrock L: Diesel exhaust particles increase LPS-stimulated COX2 expression and PGE2 production in human monocytes. $J$ Leukoc Biol 2004, 75:856-864.

20. Bauer AK, Dwyer-Nield LD, Malkinson AM: High cyclooxygenase 1 (COX-1) and cyclooxygenase 2 (COX-2) contents in mouse lung tumors. Carcinogenesis 2000, 21:543-550.

21. Hida T, Yatabe Y, Achiwa H, Muramatsu H, Kozaki K, Nakamura S, Ogawa M, Mitsudomi T, Sugiura T, Takahashi T: Increased expression of cyclooxygenase 2 occurs frequently in human lung cancers, specifically in adenocarcinomas. Cancer Res 1998, 58:3761-3764. 
22. Meyer AM, Dwyer-Nield LD, Hurteau GJ, Keith RL, O'Leary E, You M, Bonventre $\mathrm{J}$, Nemenoff RA, Malkinson AM: Decreased lung tumorigenesis in mice genetically deficient in cytosolic phospholipase A2. Carcinogenesis 2004, 25:1517-1524.

23. Peters-Golden M, Bailie M, Marshall T, Wilke C, Phan SH, Toews GB, Moore BB: Protection from pulmonary fibrosis in leukotriene-deficient mice. Am J Respir Crit Care Med 2002, 165:229-235.

24. Hayama M, Inoue R, Akiba S, Sato T: ERK and p38 MAP kinase are involved in arachidonic acid release induced by $\mathrm{H}(2) \mathrm{O}(2)$ and PDGF in mesangial cells. Am J Physiol Renal Physiol 2002, 282:F485-F491.

25. Lu Y, Wahl LM: Oxidative stress augments the production of matrix metalloproteinase-1, cyclooxygenase-2, and prostaglandin E2 through enhancement of NF-kappa B activity in lipopolysaccharide-activated human primary monocytes. J Immunol 2005, 175:5423-5429.

26. van Rossum GS, Drummen GP, Verkleij AJ, Post JA, Boonstra J: Activation of cytosolic phospholipase A2 in Her14 fibroblasts by hydrogen peroxide: a p42/44(MAPK)-dependent and phosphorylation-independent mechanism. Biochim Biophys Acta 2004, 1636:183-195.

27. Araujo JA, Barajas B, Kleinman M, Wang X, Bennett BJ, Gong KW, Navab M, Harkema J, Sioutas C, Lusis AJ, et al: Ambient particulate pollutants in the ultrafine range promote early atherosclerosis and systemic oxidative stress. Circ Res 2008, 102:589-596.

28. Castranova V: Signaling pathways controlling the production of inflammatory mediators in response to crystalline silica exposure: role of reactive oxygen/nitrogen species. Free Radic Biol Med 2004, 37:916-925.

29. Brown DM, Donaldson K, Borm PJ, Schins RP, Dehnhardt M, Gilmour P, Jimenez LA, Stone V: Calcium and ROS-mediated activation of transcription factors and TNF-alpha cytokine gene expression in macrophages exposed to ultrafine particles. Am J Physiol Lung Cell Mol Physiol 2004, 286:L344-L353.

30. Chung SW, Chung HY, Toriba A, Kameda T, Tang N, Kizu R, Hayakawa K: An environmental quinoid polycyclic aromatic hydrocarbon, acenaphthenequinone, modulates cyclooxygenase- 2 expression through reactive oxygen species generation and nuclear factor kappa $B$ activation in A549 cells. Toxicol Sci 2007, 95:348-355.

31. Mazzoli-Rocha F, Fernandes S, Einicker-Lamas M, Zin WA: Roles of oxidative stress in signaling and inflammation induced by particulate matter. Cell Biol Toxicol 2010, 26:481-498.

32. Voelkel K, Krug HF, Diabaté S: Formation of reactive oxygen species in rat epithelial cells upon stimulation with fly ash. J Biosci 2003, 28:51-55.

33. Ghio AJ, Devlin RB: Inflammatory lung injury after bronchial instillation of air pollution particles. Am J Respir Crit Care Med 2001, 164:704-708.

34. Beck-Speier I, Kreyling WG, Maier KL, Dayal N, Schladweiler MC, Mayer P, Semmler-Behnke M, Kodavanti UP: Soluble iron modulates iron oxide particle-induced inflammatory responses via prostaglandin E2 synthesis: In vitro and in vivo studies. Part Fibre Toxicol 2009, 6:34.

35. Liu M, Yang SC, Sharma S, Luo J, Cui X, Peebles KA, Huang M, Sato M, Ramirez RD, Shay JW, et al: EGFR signaling is required for TGF-beta 1 mediated COX-2 induction in human bronchial epithelial cells. Am J Respir Cell Mol Biol 2007, 37:578-588.

36. Buckman SY, Gresham A, Hale P, Hruza G, Anast J, Masferrer J, Pentland AP: COX-2 expression is induced by UVB exposure in human skin: implications for the development of skin cancer. Carcinogenesis 1998, 19:723-729.

37. $Y u L$, Deems RA, Hajdu J, Dennis EA: The interaction of phospholipase A2 with phospholipid analogues and inhibitors. J Biol Chem 1990, 265:2657-2664

38. Street IP, Lin HK, Laliberte F, Ghomashchi F, Wang Z, Perrier H, Tremblay NM, Huang Z, Weech PK, Gelb MH: Slow- and tight-binding inhibitors of the 85-kDa human phospholipase A2. Biochemistry 1993, 32:5935-5940.

39. Ackermann EJ, Conde-Frieboes K, Dennis EA: Inhibition of macrophage Ca (2+)-independent phospholipase A2 by bromoenol lactone and trifluoromethyl ketones. J Biol Chem 1995, 270:445-450.

40. Burke JE, Dennis EA: Phospholipase A2 biochemistry. Cardiovasc Drugs Ther 2009, 23:49-59.

41. Samet JM, Ghio AJ, Costa DL, Madden MC: Increased expression of cyclooxygenase 2 mediates oil fly ash-induced lung injury. Exp Lung Res 2000, 26:57-69.
42. Demers LM, Kuhn DC: Influence of mineral dusts on metabolism of arachidonic acid by alveolar macrophage. Environ Health Perspect 1994, 102(Suppl 10):97-100.

43. Beck-Speier I, Dayal N, Karg E, Maier KL, Roth C, Ziesenis A, Heyder J: Agglomerates of ultrafine particles of elemental carbon and $\mathrm{TiO}_{2}$ induce generation of lipid mediators in alveolar macrophages. Environ Health Perspect 2001, 109(Suppl 4):613-618.

44. Mohr C, Davis GS, Graebner C, Hemenway DR, Gemsa D: Enhanced release of prostaglandin E2 from macrophages of rats with silicosis. Am J Respir Cell Mol Biol 1992, 6:390-396.

45. Takahashi HK, Iwagaki H, Yoshino T, Mori S, Morichika T, Itoh H, Yokoyama M, Kubo S, Kondo E, Akagi T, et al: Prostaglandin E(2) inhibits IL-18-induced ICAM-1 and B7.2 expression through EP2/EP4 receptors in human peripheral blood mononuclear cells. J Immunol 2002, 168:4446-4454.

46. Beck-Speier I, Dayal N, Hofmann M, Karg E, Knoch C, Maier KL, Roth C, Samet JM, Ziesenis A, Heyder J: Synthesis of arachidonic acid-derived metabolites via phospholipase A2 activation in alveolar macrophages by agglomerates of ultrafine particles. Fraunhofer IRB Verlag 2002, 255-264.

47. Bonini MG, Rota C, Tomasi A, Mason RP: The oxidation of 2',7'dichlorofluorescin to reactive oxygen species: a self-fulfilling prophesy? Free Radic Biol Med 2006, 40:968-975.

48. Milne GL, Yin H, Morrow JD: Human biochemistry of the isoprostane pathway. J Biol Chem 2008, 283:15533-15537.

49. Makris D, Paraskakis E, Korakas P, Karagiannakis E, Sourvinos G, Siafakas NM, Tzanakis N: Exhaled breath condensate 8-isoprostane, clinical parameters, radiological indices and airway inflammation in COPD. Respiration 2008, 75:138-144.

50. Perez $R$, Melero R, Balboa MA, Balsinde J: Role of group VIA calciumindependent phospholipase $A 2$ in arachidonic acid release, phospholipid fatty acid incorporation, and apoptosis in U937 cells responding to hydrogen peroxide. J Biol Chem 2004, 279:40385-40391.

51. Stone V, Tuinman M, Vamvakopoulos JE, Shaw J, Brown D, Petterson S, Faux SP, Borm P, MacNee W, Michaelangeli F, et al: Increased calcium influx in a monocytic cell line on exposure to ultrafine carbon black. Eur Respir J 2000, 15:297-303.

52. Brown DM, Hutchison L, Donaldson K, Stone V: The effects of PM10 particles and oxidative stress on macrophages and lung epithelial cells: modulating effects of calcium-signaling antagonists. Am J Physiol Lung Cell Mol Physiol 2007, 292:L1444-L1451.

53. Blanusa M, Varnai VM, Piasek M, Kostial K: Chelators as antidotes of metal toxicity: therapeutic and experimental aspects. Curr Med Chem 2005, 12:2771-2794.

54. Gillissen A, Nowak D: Characterization of N-acetylcysteine and ambroxol in anti-oxidant therapy. Respir Med 1998, 92:609-623.

55. Herrlich P, Karin M, Weiss C: Supreme EnLIGHTenment: damage recognition and signaling in the mammalian UV response. Mol Cell 2008, 29:279-290.

56. Samet JM, Tal TL: Toxicological disruption of signaling homeostasis: tyrosine phosphatases as targets. Annu Rev Pharmacol Toxicol 2010, 50:215-235.

57. Stewart D, Killeen E, Naquin R, Alam S, Alam J: Degradation of transcription factor Nrf2 via the ubiquitin-proteasome pathway and stabilization by cadmium. J Biol Chem 2003, 278:2396-2402.

58. He X, Chen MG, Ma Q: Activation of Nrf2 in defense against cadmiuminduced oxidative stress. Chem Res Toxicol 2008, 21:1375-1383.

59. Aust AE, Ball JC, Hu AA, Lighty JS, Smith KR, Straccia AM, Veranth JM, Young WC: Particle characteristics responsible for effects on human lung epithelial cells. Res Rep Health Eff Inst 2002, 1-65.

60. Imrich A, Ning Y, Lawrence J, Coull B, Gitin E, Knutson M, Kobzik L: Alveolar macrophage cytokine response to air pollution particles: oxidant mechanisms. Toxicol Appl Pharmacol 2007, 218:256-264.

61. Lund LG, Aust AE: Iron mobilization from crocidolite asbestos greatly enhances crocidolite-dependent formation of DNA single-strand breaks in phi X174 RFI DNA. Carcinogenesis 1992, 13:637-642.

62. Pulskamp K, Diabaté S, Krug HF: Carbon nanotubes show no sign of acute toxicity but induce intracellular reactive oxygen species in dependence on contaminants. Toxicol Lett 2007, 168:58-74.

63. van Berlo D, Knaapen AM, van Schooten FJ, Schins RP, Albrecht C: NFkappaB dependent and independent mechanisms of quartz-induced 
proinflammatory activation of lung epithelial cells. Part Fibre Toxicol 2010,

7:13.

64. Bligh EG, Dyer WJ: A rapid method of total lipid extraction and purification. Can J Biochem Physiol 1959, 37:911-917.

doi:10.1186/1743-8977-8-23

Cite this article as: Fritsch-Decker et al:: Regulation of the arachidonic acid mobilization in macrophages by combustion-derived particles.

Particle and Fibre Toxicology 2011 8:23.

Submit your next manuscript to BioMed Central and take full advantage of:

- Convenient online submission

- Thorough peer review

- No space constraints or color figure charges

- Immediate publication on acceptance

- Inclusion in PubMed, CAS, Scopus and Google Scholar

- Research which is freely available for redistribution

Submit your manuscript at www.biomedcentral.com/submit 